\title{
Role of Oral Antioxidant Supplementation in the Current Management of Diabetic Retinopathy
}

\author{
Enrique Antonio Alfonso-Muñoz ${ }^{1}\left(\mathbb{D}\right.$, Raquel Burggraaf-Sánchez de las Matas $^{2}{ }^{(}$, Jorge Mataix Boronat $^{1}{ }^{(D)}$, \\ Julio César Molina Martín ${ }^{3}$ (i) and Carmen Desco ${ }^{1, *(1)}$ \\ 1 FISABIO-Oftalmología Médica (FOM), Vitreoretinal Unit, 46015 Valencia, Spain; \\ enalmuo@gmail.com (E.A.A.-M.); jorge.mataix@gmail.com (J.M.B.) \\ 2 Servicio de Oftalmología, Hospital General Universitario de Castellón, 12004 Castellón, Spain; \\ raquelburggraaf@gmail.com \\ 3 Servicio de Oftalmología, Hospital Universitario San Juan, 03550 Alicante, Spain; jcmm.molina@gmail.com \\ * Correspondence: carmen.desco@uv.es
}

check for

updates

Citation: Alfonso-Muñoz, E.A.; Burggraaf-Sánchez de las Matas, R.; Mataix Boronat, J.; Molina Martín, J.C.; Desco, C. Role of Oral Antioxidant Supplementation in the Current Management of Diabetic Retinopathy. Int. J. Mol. Sci. 2021, 22, 4020. https://doi.org/10.3390/ ijms22084020

Academic Editor: Alexander V. Ljubimov

Received: 2 March 2021

Accepted: 9 April 2021

Published: 13 April 2021

Publisher's Note: MDPI stays neutral with regard to jurisdictional claims in published maps and institutional affiliations.

Copyright: (C) 2021 by the authors Licensee MDPI, Basel, Switzerland. This article is an open access article distributed under the terms and conditions of the Creative Commons Attribution (CC BY) license (https:// creativecommons.org/licenses/by/ $4.0 /)$.

\begin{abstract}
Oxidative stress has been postulated as an underlying pathophysiologic mechanism of diabetic retinopathy (DR), the main cause of avoidable blindness in working-aged people. This review addressed the current daily clinical practice of DR and the role of antioxidants in this practice. A systematic review of the studies on antioxidant supplementation in DR patients was presented. Fifteen studies accomplished the inclusion criteria. The analysis of these studies concluded that antioxidant supplementation has a IIB level of recommendation in adult Type 1 and Type 2 diabetes mellitus subjects without retinopathy or mild-to-moderate nonproliferative DR without diabetic macular oedema as a complementary therapy together with standard medical care.
\end{abstract}

Keywords: diabetic retinopathy; antioxidants; oxidative stress; management; clinical practice; ophthalmology; retina; nutrition; nutraceuticals; multivitamin complex

\section{Introduction}

Diabetic retinopathy (DR) is one of the most specific microvascular complications in diabetes mellitus (DM) and is the main cause of avoidable blindness in working-aged people [1-3]. As it develops, and depending on the duration of DM and glycaemic levels, it is expected to increase concurrently as diabetes numbers rise [1]. According to the most recent International Diabetes Federation data, the worldwide prevalence of DM was estimated to be $9.3 \%$ (463 million people) in adults aged $20-79$ years old in 2019 , and these numbers are expected to increase to $10.9 \%$ (700.2 million people) by 2045 , thereby constituting a global burden for the Public Health Care Systems that will not stop increasing [2].

One of the main concerns is that patients can remain asymptomatic until visual symptoms begin. The current management of DR comprises accurate screening programmes for early detection and a strict systemic control of glycaemia and related risk factors; however, active treatment is not initiated until advanced stages of the disease occur [3]. Taking into account that up to $45.8 \%$ of the world diabetic population is estimated to be undiagnosed, many are checked once DM complications have already developed, when tissue damage may be irreversible [4]. There is still a gap for new diagnostic biomarkers and for active treatments that could be applied in the early stages of DR to prevent further progression.

Oxidative stress has been demonstrated to play a key role in the pathophysiology of DR and has been postulated as a nexus with other biochemical pathways, which commonly brings about inflammation, neurodegeneration, and microvasculopathy [5,6]. The use of antioxidants, such as polyphenols, has proved to reduce DR progression in animal models [7]. However, their role in the clinical management of DR patients has not yet been established. We presented updated guidelines on DR followed by a systematic review of 
antioxidant clinical trials discussing when, how and why antioxidant supplementation should be used in DR management.

\section{Epidemiology and Risk Factors}

According to the latest published report by the Vision Loss Expert Group in 2015, DR dropped from fifth to sixth place of the most common cause of preventable vision impairment globally [8], in comparison with their previous report in 2010 [9]. Nevertheless, while blindness and vision impairment due to all causes has decreased, DR was the only eye disease that had risen in terms of crude global prevalence since 1990: DR-blindness increased by $7.7 \%$ and DR moderate-to-severe vision impairment increased by $28.6 \%$ in 2015. This was a warning signal to strengthen existing screening programmes and management strategies and increase research programmes directed towards new molecular targets before the disease appears $[8,10]$.

In 2010, the global prevalence of DR among the diabetic population was estimated to be about $34.6 \%$ with regard to DR of any kind, $6.96 \%$ for proliferative diabetic retinopathy (PDR), $6.81 \%$ for diabetic macular oedema (DME), and $10.2 \%$ for vision-threatening diabetic retinopathy (VTDR), including PDR and DME. This means that approximately one third of DM patients would have some degree of DR and one tenth needs active treatment. The risk of having some kind of DR was 2.7 times higher in type $1 \mathrm{DM}$ (T1DM) than in type 2 DM (T2DM) after at least 20 years of disease progression [1].

Regarding DR global incidence, a recent nine-year prospective population-based study including T1 and T2 patients determined an annual incidence of $15.16 \pm 2.19 \%$ in T1DM, in comparison to $8.37 \pm 2.19 \%$ in T2DM. In both the duration of DM and glycaemic control, together with arterial hypertension, low-density lipoprotein (LDL) cholesterol and creatinine levels were significant risk factors for developing DR, both in T1DM and T2DM. A higher prevalence and incidence of DR observed in the T1DM sample at the end of this study was attributed to a longer duration of diabetes and worse basal and monitored $\mathrm{HbA1c}$ levels [11].

In the context of dietary patterns, there is evidence that dietary fibre, oily fish and the Mediterranean diet can protect against DR. By contrast, a higher caloric intake has been associated with a greater risk for DR. In addition, a recent review reported that studies on antioxidants, specifically vitamins $\mathrm{C}, \mathrm{E}$ and carotenoids as protective factors in usual diets, are inconclusive [12].

\section{Pathophysiology}

Diabetic retinopathy must be considered as multifactorial, as its development is a direct consequence of prolonged levels of hyperglycaemia, although it is influenced by the previously mentioned risk factors $[1,11,13,14]$.

From a metabolic perspective, an exacerbated oxidative stress environment has been found to be a crucial factor in the development of DR, interacting as a link between other glucose-mediated biochemical processes. An excess of glucose causes the activation of the polyol pathway, the production of advanced glycation end products (AGEs), the activation of protein kinase $\mathrm{C}$ (PKC) and an increase in the hexosamine pathway. All together, these contribute to an increase in the production of reactive oxygen species (ROS) $[5,6,15]$. Although these molecules are continuously produced for normal cell function, they are neutralised through physiological antioxidant systems. Moreover, ROS accumulation triggers structural changes concerning mitochondrial DNA and the subsequent modifications in gene expression. The impact of oxidative stress on diabetes is not temporary, because mitochondrial dysfunction involves the exacerbation of the production of ROS [16,17]. This occurrence, described as the metabolic memory, has been postulated to be responsible for disease progression even after achieving correct glycaemic control [18]. Among the cited risk factors for DR, arterial hypertension has been demonstrated to increase glycaemicinduced oxidative stress, contributing to the exacerbation of molecular damage [19]. 
Metabolic alterations produced by hyperglycaemia and an increase in ROS result in cellular dysfunction and sequential apoptosis, leading to [20]:

- Inflammation: Microglial activation seems to be an early event in DR and can trigger the secretion of inflammatory mediators [21,22]. Proinflammatory cytokines (interleukins IL-1 $\beta$, IL-6, IL- 8 and TNF- $\alpha$ ) have been reported in higher levels in human vitreous samples [23,24], and have also correlated with the severity of DR [25]. Under inflammatory stimuli, endothelial cells increase the expression of intracellular and vascular adhesion molecules (ICAM-1 and VCAM-1) and E-selectin, allowing leukocyte adhesion to the endothelial cell walls and the production of leukostasis, which is a determining factor for posterior microvascular damage [26,27]. Increased levels of the above-mentioned molecules have been reported in diabetic blood samples [28], and the inhibition of ICAM-1 in cultured human retinal endothelial cells from diabetic patients reduced cell apoptosis. Interestingly, the use of an antioxidant agent reduced the levels of ICAM-1 on those retinal cultures and was able to reduce cellular loss [29].

- Neurodegeneration: Apoptosis seems to affect neurons before vascular cells. Electroretinogram (ERG) studies have shown the possibility of existing neuronal damage even before DR clinical signs were present, preceding microvascular changes. Furthermore, retinal analysis has demonstrated a thinner ganglion cell inner layer both in diabetic animal models and human subjects [30-32]. With regard to the role of oxidative stress in relation to neurodegeneration, ERG studies have been carried out on induced-diabetes mice, before and after antioxidant administration, thus verifying the protective role of lutein both on visual function and histological neuronal changes [31].

- Microvasculopathy: The walls of retinal capillaries have an external pericytes layer, a basement membrane and an inner endothelial cells layer. Pericyte loss occurs under hyperglycaemic conditions [33] and leads to focal microvascular dilatation with microaneurysm formation. A thickening of the basement membrane, due to debris deposition and endothelial cell dysfunction, leads to blood-retinal barrier (BRB) disruption, producing increased vascular permeability with exudation and haemorrhages [34]. Leukostasis derived from an inflammatory response is involved in endothelial cell impairment and is followed by microvascular occlusions [27]. Subsequent hypoxia promotes the activation of transcription factor hypoxia-inducible factor 1 (HIF-1), which further stimulates the secretion of vascular endothelial growth factors (VEGFs), and therefore causes neovessel formation [35].

\section{Important Role of Early Diagnosis}

\subsection{Classification of $D R$}

Fundoscopy clinical signs derived from tissue damage have suggested a sequential grading of DR. In 2002, in an attempt to simplify the daily clinical practice, the Global Diabetic Retinopathy Project Group proposed the International Clinical Disease Severity Scale for DR, as shown in Table 1 [36].

A recent multicentre cohort study performed in the UK analysed the five-year risk of developing PDR depending on the stage at baseline. The probability of presenting PDR at year five was $2.2 \%$ for no initial DR, $13 \%$ for mild nonproliferative diabetic retinopathy (NPDR) at baseline, 27.2\% for moderate NPDR and 45.5\% for severe NPDR [37].

Diabetic macular oedema (DME) has been classified separately, as it can appear at any of the mentioned stages of DR. The International Scale understood DME to be the retinal thickening or presence of hard exudates in the posterior pole, and it was graded into three stages [23] (Table 1 and Figure 1). 
Table 1. International Clinical Disease Severity Scale for diabetic retinopathy (DR).

\begin{tabular}{|c|c|}
\hline Disease & Ophthalmoscopy Findings \\
\hline No apparent DR & No ocular findings \\
\hline NPDR & No NV \\
\hline Mild & Microaneurysms only \\
\hline Moderate & $\begin{array}{l}\text { Microaneurysms + blot haemorrhages, hard exudates, cotton wool spots } \\
\text { (but less than in severe NPDR) }\end{array}$ \\
\hline Severe & $\begin{array}{c}\text { Intraretinal haemorrhages ( } \geq 20 \text { in each quadrant) } \\
\text { Definite venous beading (in two quadrants) } \\
\text { Intraretinal microvascular abnormalities (IRMA) (in one quadrant) } \\
\text { No signs of proliferative retinopathy }\end{array}$ \\
\hline PDR & $\begin{array}{c}\text { Neovascularisation or vitreous/preretinal haemorrhage/tractional retinal } \\
\text { detachment }\end{array}$ \\
\hline \multicolumn{2}{|r|}{ DME = retinal thickening of hard exudates in the posterior pole } \\
\hline Mild & $\begin{array}{l}\begin{array}{l}\text { Some retinal thickening or hard exudates in the posterior pole but distant } \\
\text { from the centre of the macula }\end{array}\end{array}$ \\
\hline Moderate & $\begin{array}{l}\text { Retinal thickening or hard exudates approaching the centre of the macula } \\
\text { but not involving the fovea }\end{array}$ \\
\hline Severe & Retinal thickening or hard exudates involving the centre of the macula \\
\hline
\end{tabular}

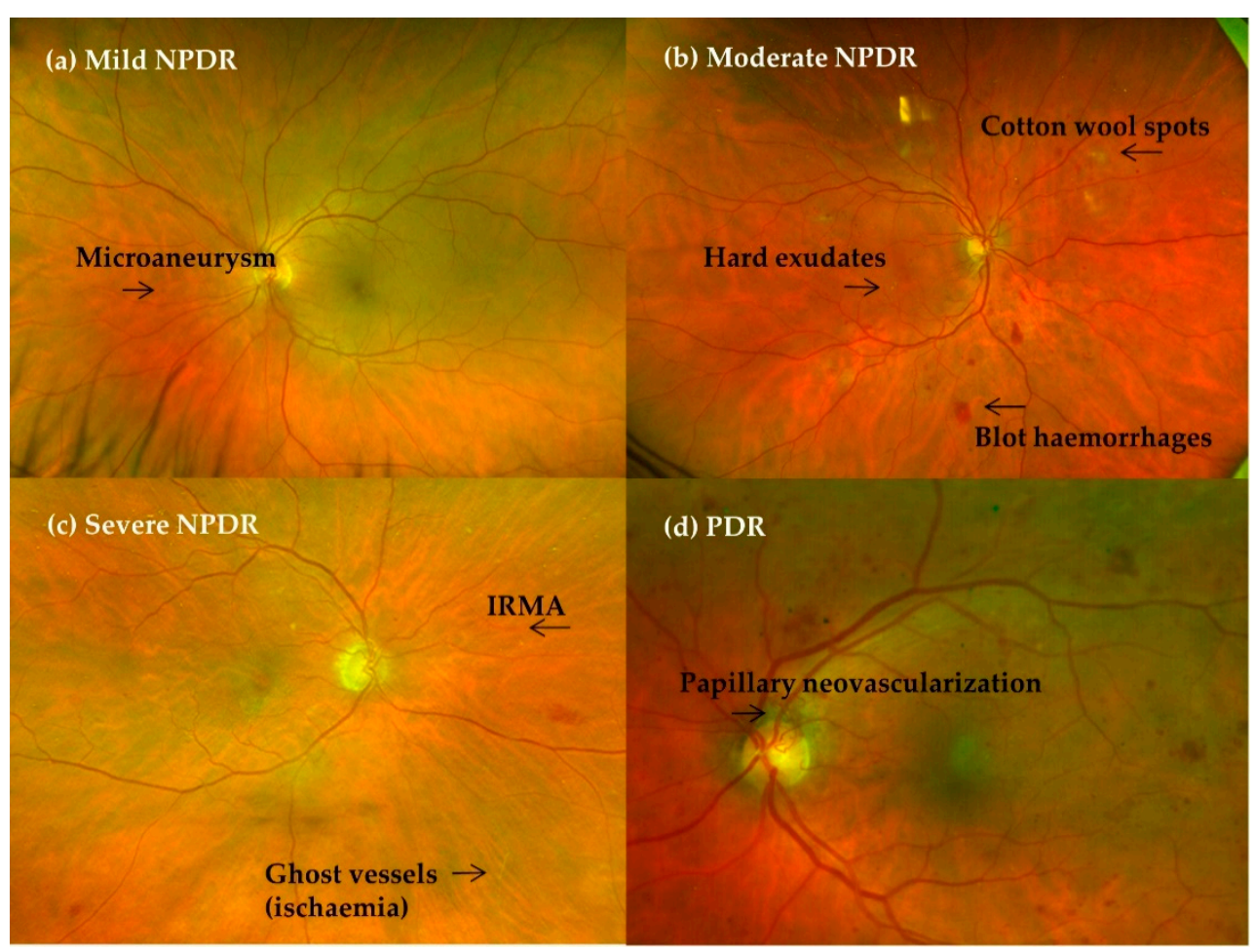

Figure 1. Clinical DR progression. (a) Mild nonproliferative diabetic retinopathy (NPDR), (b) moderate NPDR, (c) severe NPDR and (d) proliferative diabetic retinopathy (PDR) with papillary neovascularisation.

\subsection{Impact on Visual Impairment}

Studies that have measured quality-of-life items reported vision-related effects on emotional well-being and general health, especially in those suffering from VTDR, con- 
tributing to a lack of economic development [38,39]. DME is the most common reason for visual acuity (VA) loss, followed by any context of PDR [1,11].

From the viewpoint of ophthalmological care, the active treatment of DR should be initiated when a high risk of progression to PDR or DME [3] is evident. It must be kept in mind that advanced stages of DR or DME may translate into extensive tissue damage with dysfunctional cells due to the metabolic memory effect $[18,40,41]$ and, therefore, make it too late to restore adequate visual function.

\section{Imaging Techniques for Diabetic Retinopathy Screening}

The exponential increase in diabetes worldwide has forced the development of several imaging diagnostic tools that can screen for DR in a fast and effective way. Traditionally, most DR screening programmes have been based on fundus photography (FF) with mydriatic or nonmydriatic cameras to identify DR patterns. Nowadays, imaging technology has made a significant quantitative and qualitative leap forward, providing a great improvement in terms of affordability, performance and diagnostic accuracy. Funduscopic imaging using smartphones, macular optical coherence tomography (OCT) and ultrawide-field imaging, together with revolutionary artificial intelligence (AI) software, has opened the door to a new era in the early diagnosis and follow-up of DR patients.

The International Council of Ophthalmology (ICO) guidelines for DR diagnosis include retinal examination with either (a) direct or indirect ophthalmoscopy or fundus biomicroscopy using a slit lamp, or (b) mono-photography or stereo-photography greater than or equal to $30^{\circ}$, associated or not with OCT. These images should always be analysed and classified by a trained specialist [3]. The accuracy of DR classification provided by these screening tools is considered to be category 1, as defined by the American Teleophthalmological Association (ATA), and it provides a sufficiently high level of accuracy for population screening.

\subsection{Fundus Photography}

Today's digital FF is a reliable alternative to the traditional seven-field photography used in early treatment diabetic retinopathy studies (ETDRSs) [42]. Current fundus cameras have resolutions in the range of 20 megapixels, exceeding the 2-3-megapixel resolution needed to display a single retinal microaneurysm [43]. Several clinical trials have shown that mydriatic FF has a higher sensitivity and specificity for DR detection compared to nonmydriatic cameras [43]. However, due to practical and logistical considerations, most DR detection programmes use nonmydriatic FF. Most modern programmes use a single $45^{\circ}$ photograph or even two or three multi-field photographs [44].

The ATA establishes four levels of grading systems for DR. Level 1 includes programmes that can distinguish between the absence of DR and minimal DR disturbances. Level 4 can make a complete DR categorisation between mild, moderate, severe and early proliferative high-risk DR, with or without macular oedema [44].

\subsection{Ultrawide-Field Imaging for Diabetic Retinopathy Screening}

Wide-field photography is another DR screening modality, which is especially appropriate for detecting peripheral ischaemic lesions and proliferative diabetic retinopathy [45]. Ultrawide-field imaging reaches $80 \%$ of the retinal surface and detects DR with a $99 \%$ sensitivity and $97 \%$ specificity [46].

\subsection{Optical Coherence Tomography for Diabetic Macular Oedema Screening}

As mentioned above, FF is a useful diagnostic tool for DR, but it has a low accuracy in detecting diabetic macular oedema (DME) due to its two-dimensional nature and because it is unable to measure retinal thicknesses reliably. The English National Screening Program for the detection of DME uses three photographic landmarks: first, the appearance of exudates within one disc diameter from the fovea; second, the presence of circinate exudates within the macula; and third, the presence of microaneurysms or haemorrhages within 
one disc diameter from the fovea [47]. However, this method yields limited diagnostic utility. Conventional FF offered an $86.6 \%$ false positive rate in detecting DME, according to a cross-sectional observational study [48]. For this reason, macular OCT is a better option than FF for evaluating the macula. Several studies have investigated the cost-effectiveness and efficiency of using macular OCT in DME detection programmes [49].

OCT allows for a detailed analysis of all the retinal layers. For example, it quantifies the thinning of the ganglion cell and nerve fibre layer due to the neurodegenerative process present in DR patients. It may also show the disorganisation at the macular internal retinal layer (DRIL) as a biomarker of visual impairment [50]. Alternatively, it may evaluate the integrity of the outer layers where the cone photoreceptors and the pigment epithelium cells of the retina are present.

\subsection{OCT Angiography in Diabetic Retinopathy Screening}

OCT angiography (OCT-A) is a novel noninvasive imaging modality able to describe the retinal circulation using algorithms that detect red blood cell movement. This technique can detect microaneurysms, retinal neovascularisation or ischaemic areas, but only in the posterior pole; it cannot evaluate the peripheral retina [51]. Therefore, it can classify DR according to its severity. It describes the anatomy and blood flow at the foveal avascular zone and the superficial and deep retinal plexus in the macula [51,52]. OCT-A can also measure the progression of DR as it correlates vascular changes with visual acuity [53].

\subsection{Smartphone Function in Diabetic Retinopathy Screening}

Most digital FF cameras and OCTs are expensive and require trained specialists in retinal image interpretation. To solve this problem, several smartphone applications have been developed as effective and accessible techniques for DR detection. Cameras in modern cell phones have an even higher resolution than other conventional fundus cameras. Newgeneration smartphones have wide-field digital cameras with resolutions greater than 10 megapixels [44]. Currently, these smartphones need the coupling of supplementary lenses and specific image editing software. Several clinical trials have demonstrated the potential of these devices to detect DR in different regions of the world [54].

\subsection{Automated DR Image Evaluation Systems Used for Teleophthalmology}

Gardner and colleagues described the use of an artificial neural network able to detect DR with an $88 \%$ and $83 \%$ sensitivity and specificity, respectively, as compared to a trained ophthalmologist [55]. These systems use pattern recognition algorithms that identify specific features of DR, such as microaneurysms. On the downside, the image pre-processing requires a lot of time in order to identify clinically important features and develop mathematical descriptors for the different types of lesions.

Deep learning (DL) is a novel AI iteration that employs convolutional neural networks to interpret images by repetitive analysis and comparison of the output with a standard that is self-correcting if an error is made. Multiple studies have demonstrated useful results in the development of DL algorithms that are able of identify references of DR without the need to previously teach computer systems specific DR characteristics. The sensitivity and specificity of these approaches are generally $90 \%$ and $95 \%$, respectively [56,57]. The present generation of DL algorithms employing coloured FF has achieved a rating performance similar to that of a retinal specialist [58]. Several DL algorithms for DR detection, including the recently FDA-approved IDx-DR algorithm [59], have been described. These systems are trained using known features of DR, such as microaneurysms, bleeding and exudates.

\section{Pathology Control and Monitoring}

The correct management of a disease usually depends on the good practice of doctors, their diagnosis and application of the appropriate treatment. However, controlling a highprevalence disease, such as DR, which affects almost 100 million people worldwide [1], needs more than diagnosis and treatment; it requires good follow-up protocols in order 
to optimise health resources and focus attention on patients who are more susceptible to having vision loss complications.

\subsection{First Visit}

Knowing when to first examine a diabetic patient for DR signs is the first step in controlling and preventing the pathology.

Guidelines differ: UK guidelines recommend to start DR screening in all persons diagnosed with diabetes aged 12 and over [60] as a result of research including 2125 children under 12-years-old diagnosed with DM, showing that only three children $(0.17 \%)$ presented sight-threatening conditions, and none required treatment [61]. The American Academy of Ophthalmology Guideline recommends to start screening five years after the diagnosis of T1DM and when T2DM is diagnosed [62].

The first visit is most important and should incorporate the following crucial actions:

\subsubsection{Grade the Diabetic Retinopathy}

The main goal of ophthalmologists and general doctors treating DR patients is to avoid vision loss complications of DR, diabetic macular oedema (DME) and proliferative diabetic retinopathy (PDR). In order to plan a good strategy to prevent these complications, $\mathrm{DR}$ has been divided into different grades depending on the probability of developing these complications and the guidance for their management.

Following the International Classification of Diabetic Retinopathy and Diabetic Macular Edema [3], the risk of developing PDR and the proposed follow-up time in each DR grade are listed in Table 2.

Table 2. Management of DR patients depending on the pathology grade.

\begin{tabular}{|c|c|c|c|c|c|c|c|}
\hline & \multirow[t]{2}{*}{ No DR } & \multicolumn{3}{|c|}{ NPDR } & \multirow[t]{2}{*}{ PDR } & \multicolumn{2}{|c|}{ DME } \\
\hline & & Mild & Moderate & Severe & & $\begin{array}{l}\text { Non-Centre } \\
\text { Involving }\end{array}$ & Centre \\
\hline $\begin{array}{l}\text { PDR progression } \\
\text { risk within } \\
1 \text { year } / 3 \text { years }\end{array}$ & $5 \% / 14 \%$ & $12-27 \% / 30.48 \%$ & $52 \% / 71 \%$ & & & & \\
\hline $\begin{array}{c}\text { Referral to } \\
\text { ophthalmologist }\end{array}$ & $\begin{array}{l}\text { Not } \\
\text { required }\end{array}$ & Not required & Required & Required & Required & $\begin{array}{l}\text { Recommended } \\
\text { if laser sources } \\
\text { available* }\end{array}$ & Required \\
\hline Treatment & Obs & rvation & Observation/PRP & P PRP & $\begin{array}{c}\text { Anti- } \\
\text { VEGF/PRP/VPP }\end{array}$ & $\begin{array}{c}\text { Laser: } \\
\text { Focal/Grid }\end{array}$ & Anti-VEGF \\
\hline Antioxidants role & \multicolumn{3}{|c|}{ Potentially indicated } & \multicolumn{2}{|c|}{ Worthwhile? } & \multicolumn{2}{|c|}{ Potentially indicated } \\
\hline Follow-up & $1-2$ years & $\begin{array}{l}\text { 6-12 months / } \\
1-2 \text { years * }\end{array}$ & $\begin{array}{l}3-6 \text { months / } \\
6-12 \text { months * }\end{array}$ & $<3$ months & $\begin{array}{l}<1 \text { month } \\
\text { If stabilised: } \\
6 \text { to } 12 \text { months }\end{array}$ & 3 months & 1 month \\
\hline
\end{tabular}

$\mathrm{DR}$ = diabetic retinopathy; $\mathrm{NPDR}=$ nonproliferative diabetic retinopathy; $\mathrm{NV}=$ neovascularisation; $\mathrm{PDR}$ = proliferative diabetic retinopathy; $\mathrm{DME}$ = diabetic macular oedema; $\mathrm{PRP}=$ panretinal photocoagulation; FA = fluorescein angiography; PPV = pars plana vitrectomy, VEGF $=$ vascular endothelial growth factor. ${ }^{*}$ Specific recommendations for low or intermediate resource settings [3].

Apart from a normal ophthalmology examination including funduscopy, other important complementary explorations to grade DR at the first visit are strongly recommended:

- Wide-field fluorescein angiography (WF-FA): Though some guidelines recommend performing FA on a case-by-case basis prior to macular laser treatment [60], analysing peripheral retina vascularisation is fundamental for DR management as global ischaemia is related to neovascularisation, which indicates treatment to prevent PDR [63]. As wide-field OCT angiography (WF-OCTA) is as yet uncommon, our group recommend performing a WF-FA at a moderate NPDR stage. WF-FA is also, to date, the 
best exploration for grading DR [64], detecting 1.6 to 3.5-fold more fields affecting DR severity than ultrawide-field colour imaging (Figure 2).

- $\quad$ Optical coherence tomography (OCT): OCT should be mandatory at every DR visit as several DMEs can only be seen in OCT examination. OCT is also the most useful imaging modality for calculating and monitoring the individual treatment response to anti-VEGF treatment [65].

- OCT angiography (OCT-A): OCT-A can demonstrate areas of capillary nonperfusion and it is very useful for assessing patients with DR and loss of visual acuity without central oedema. An increase in the area of the foveal avascular zone has been associated with worse visual acuity [60,66-68] (Figure 3).

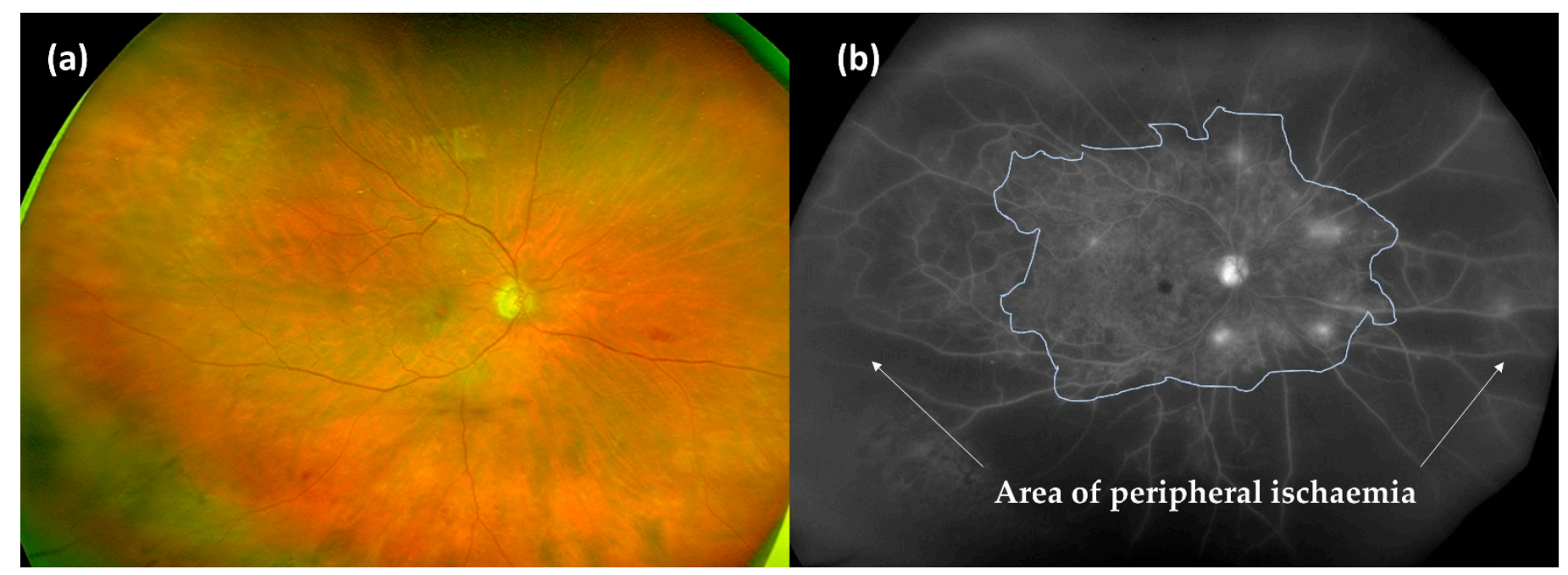

Figure 2. Wide-field photography (a) and its correspondent wide-field fluorescein angiography (WF-FA) (b). Surprisingly, the ischaemic areas (white arrows) in WF-FA are much larger than was suspected with funduscopy findings, which clearly changes the DR grading.

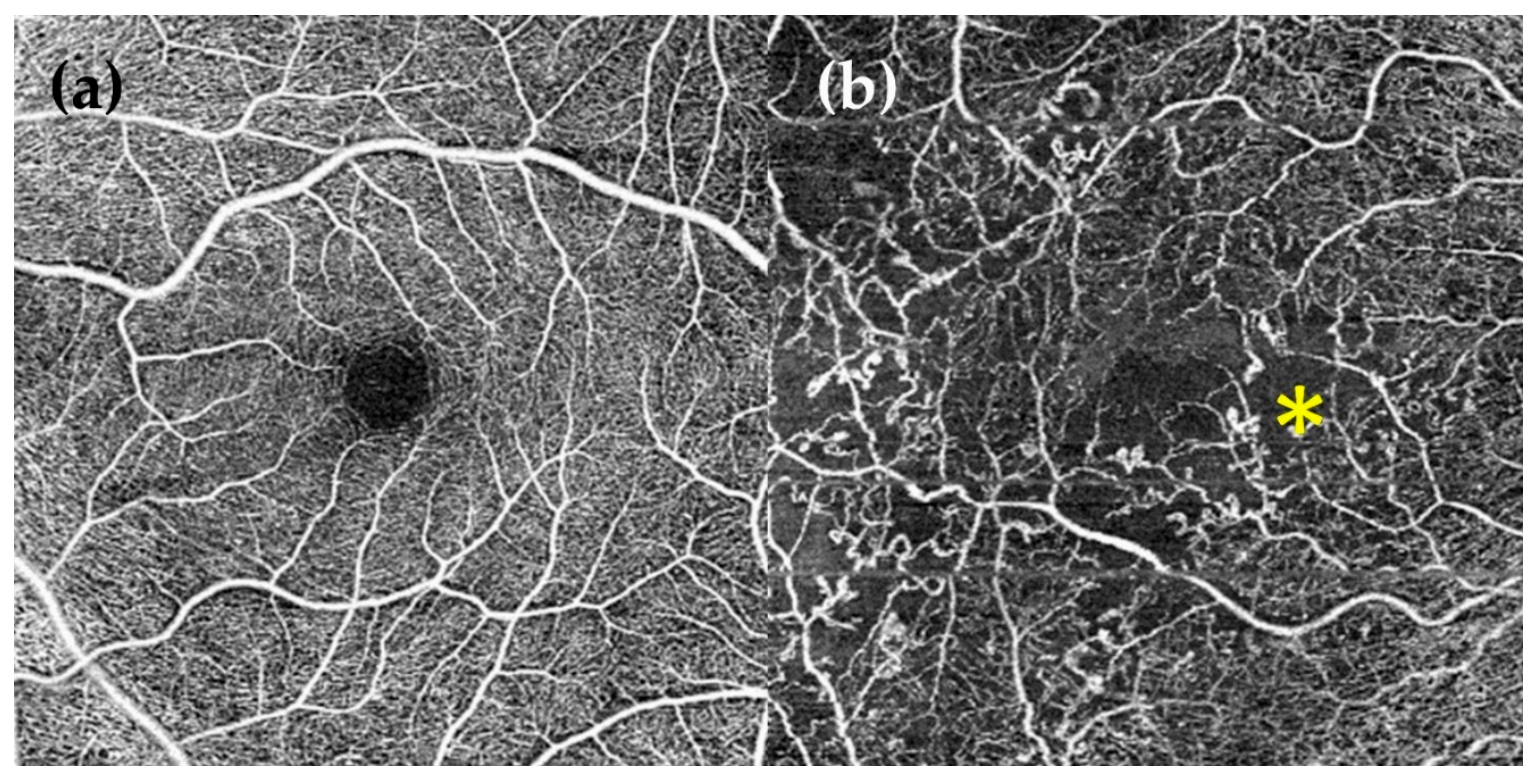

Figure 3. Optical coherence tomography angiography (OCT-A) of $6 \times 6 \mathrm{~mm}$. (a) Healthy eye. Normal foveal avascular zone (FAZ); (b) DR eye. Abnormal changes in FAZ size and shape. Microaneurysms (*), vessels loops, tortuosity and a reduction of capillary density can be observed. 


\subsubsection{Educational Advice}

Once the DR of the patient has been graded, educational advice on the first visit is fundamental to encourage patients to attend their routine appointments. A retrospective audit of data from 62,067 patients due for annual diabetes eye screening showed that missing appointments strongly increased the proportion of patients showing referable retinopathy at the next visit. Particular focus must be put on young T1DM male patients who are the most likely to miss appointments [69]. At this point, general practitioners, endocrinologists and ophthalmologists should work together throughout the whole follow-up.

A proposed scheme of the advice is:

DR is the first cause of blindness in working-age people [8]. DR is a reflection of systemic affection by diabetes, and in fact, the presence of mild NPDR implies an excess of mortality of $81 \%$ and a moderate-severe NPDR of $314 \%$ [70]. As a result, uncontrolled $\mathrm{DR}$ is a reflection of uncontrolled diabetes, increasing possibilities of not only blindness, but also death due to some other cause. However, blindness caused by DR is almost $100 \%$ avoidable following our recommendations [71].

\subsubsection{Establishing Goals for Controlling the Risk Factors Associated with DR Progression}

While DR is in its early stages, the risk of losing vision is low and controlling the risk factors associated with the development and progression of DR is the only treatment we can offer patients. Specific goal values have to be established. The main goals for DR control are to regulate $\mathrm{HbA1c}$ and blood pressure (BP). Secondary goals include lowering serum lipids and obesity.

- $\mathrm{HbA} 1 \mathrm{c}<7 \%$ : HbA1c control has a memory effect, in other words, the effect of the correct control over time protects against the progression of DR in the case of a future uncontrolled period [72]. Therefore, the early intervention in this parameter is essential. A $1 \%$ reduction in $\mathrm{HbA} 1 \mathrm{c}$ is associated with a $35 \%$ reduction in the risk of developing DR, $15-25 \%$ in its progression, $25 \%$ in VA loss and $15 \%$ in developing blindness [73]. In T1DM compared to HbA1c of 9\%, HbA1c under 7\% diminishes the development of DR in $75 \%$ of cases and progression in $50 \%$. Despite the importance of diminishing $\mathrm{HbA} 1 \mathrm{c}$, this reduction should not be acute, because, apart from the risk of hypoglycaemia, this reduction could promote DR progression, as shown in a study focusing on obese patients who underwent bariatric surgery. Notably, $18.9 \%$ of the patients who did not have DR before surgery developed DR in the first year after the procedure [74]. A DR study by an ophthalmologist is recommended before bariatric surgery. The goal of a $\mathrm{HbA} 1 \mathrm{c}$ under $7 \%$ is variable depending on the patient [75]. A value under $6.5 \%$ is recommended if there is a risk of nephropathy and DR. A value between 7.1 and $8.5 \%$ could be tolerated if there are multiple comorbidities and if, despite maximum treatment, it is difficult to reach a value below $7 \%$.

- $\quad \mathrm{BP}<150 / 85$ : When comparing patients with BPs under 180/10 mmHg with patients under $150 / 85 \mathrm{mmHg}$, there is a $33 \%$ reduction in the progression of DR and the necessity of laser treatment and a 50\% reduction in vision loss in patients with lower BPs [76]. Although these data are classic, two more modern reviews and a metaanalysis indicate that reducing BP prevents the development of DR for up to four to five years [77] and reduces the relative risk of incidence of DR by 17\% [78], but there is no clear evidence on slowing the progression once the disease has developed. In contrast to glycaemic control, BP control does not have a memory effect; once it becomes decompensated, the risk of progression of the disease increases regardless of the previous control.

- Lipid control: Two randomised control trials (RCTs) have independently demonstrated that fenofibrate reduces DR progression in T2DM and the need for laser treatment $[79,80]$.

- Obesity: A meta-analysis published in 2018 showed that obesity increased DR with a relative risk of 1.2, more in T2DM. Obesity was not associated with PDR [81]. 
- Smoking: The association of smoking and DR has been established for T1DM, but not for T2DM [82].

Controlling these risk factors in DR patients by means of antioxidant supplementation is discussed further in the antioxidant review.

\subsection{Follow-Ups}

Follow-ups should be scheduled in accordance with the recommendations of the International Classification of Diabetic Retinopathy and Diabetic Macular Edema [3]. In follow-up visits, every patient should be regraded by exploring their visual acuity, fundus, and periphery of the retina, and by performing an OCT. The following visit should be programmed depending on the new grade of the DR. It is necessary to go over the educational advice.

A general scheme of the first ophthalmology visit and the management of the disease is presented in Figure 4 and Table 2.
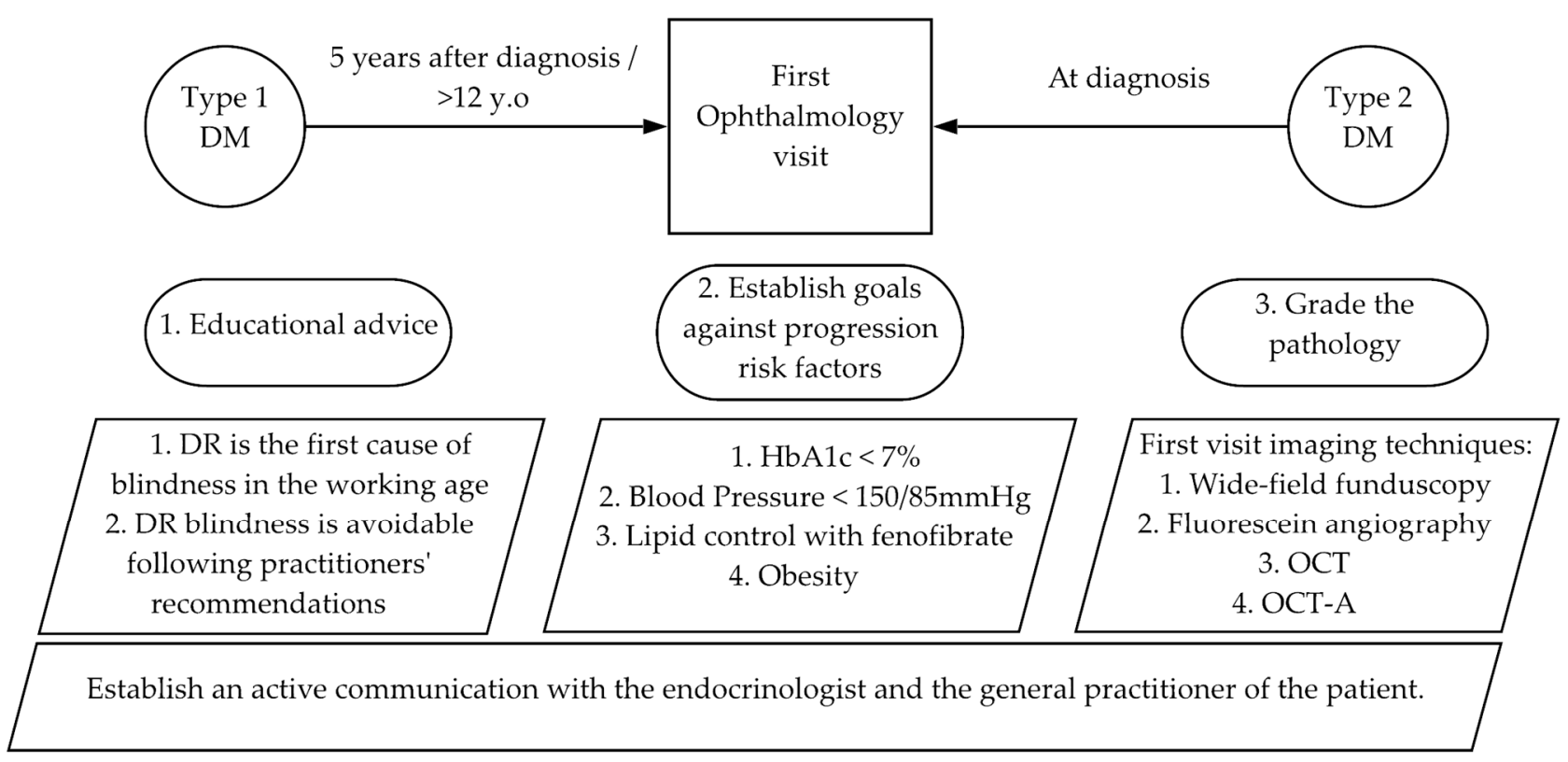

Figure 4. The first ophthalmology visit of a DR patient.

\subsection{Consideration of Special Situations \\ 6.3.1. DR and Pregnancy}

DM is estimated to affect $17 \%$ of pregnancies worldwide [83]. The majority suffer from gestational DM, which is not associated with DR, but cases of undiagnosed T2DM may be detected during pregnancy, and this group could develop DR during or after pregnancy. DR is present in 14\% of T2DM pregnant women [84] and between 34\% and $72 \%$ of T1DM $[85,86]$ pregnant women. As pregnancy increases the short-term risk of DR progression [86], pregnancy is recommended to be planned earlier, especially in T1DM, and screening during this period should be optimised.

Ophthalmologic explorations should be carried out before pregnancy and at the 28th week of amenorrhea (WA). If the pregnant woman has already been diagnosed with DR, an additional examination should be performed at 16 to $20 \mathrm{WA}$.

During the postnatal period, retinopathy that progresses during pregnancy usually tends to regress [87]. Screening should be advised up to 12 months if retinopathy has progressed during the third trimester.

If the patient has PDR, panretinal laser photocoagulation (PRP), ideally before the commencement of pregnancy, is recommended [88,89]. 
In the case of progressive DME needing treatment, the intravitreal injection of steroids is the best option [90-92], and no side effects in pregnancy have been reported.

A recent randomised controlled trial addressing antioxidant supplementation during pregnancy and diabetes showed that magnesium-zinc-calcium-vitamin D co-supplementation for six weeks in women with gestational diabetes reduced biomarkers of inflammation and oxidative stress, such as serum C-reactive protein and plasma malondialdehyde concentrations. A decreasing trend in the weight of newborns and the rate of macrosomia was also observed [93].

\subsubsection{DR and Cataract}

DR and DME progress faster after cataract surgery, meaning that screenings should be increased after the operation [94]. The rate of developing treatment-requiring DME increases sharply in the year after cataract surgery for all grades of retinopathy, peaking in the 3-6 months' postoperative period [95]. It is strongly recommended to stabilise DR and DME before surgery [96].

In cases where funduscopy is not possible, because of cataract opacity, it has to be evaluated as soon as possible after surgery in order to apply the correct treatment.

Adding an intravitreal injection of bevacizumab or triamcinolone to reduce the risk of DR progression is recommended during or after cataract surgery in patients with DR [97-99]. With the advent of PRP in the 1970s, the risk of severe vision loss from PDR was reduced by more than 90\%. The Diabetic Retinopathy Study (DRS) showed that PRP reduced the risk of severe vision loss in eyes affected with PDR [100,101].

This review could find no study on the effect of antioxidant supplementation for the prevention of DME after cataract surgery in diabetic patients. A study in this direction could be of interest as DME is a high-burden cataract complication in these patients.

\section{Current Medical Treatment and Future Therapeutic Approaches}

\subsection{Nonsevere Proliferative Diabetic Retinopathy. Anti-VEGF, PRP or Both?}

Panretinal laser photocoagulation is effective in preserving central vision but can be associated with an exacerbation of macular oedema, loss of visual field, impaired night vision and loss of contrast sensitivity. Nevertheless, laser PRP has been considered the mainstay of treatment for PDR for a long time (Figure 5).

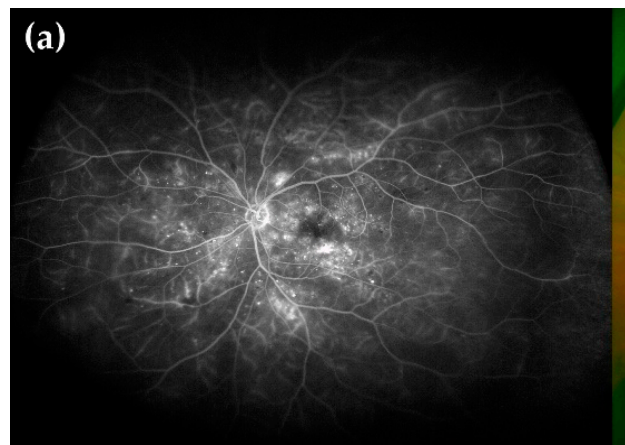

(b)

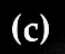

Figure 5. (a) Wide-field (WF)-Fluorescein angiography (FA) showing peripheral ischaemia and a generalised exudation. (b) Wide-field funduscopy showing laser spots after a panretinal photocoagulation (PRP) procedure. (c) No exudation is observed in the WF-FA after the PRP procedure, meaning pathology control.

It is known that high VEGF concentrations in the posterior segment of the eye are involved in the development of diabetic retinopathy and DME [102,103]. Anti-VEGF therapy for patients with DME showed a rapid regression of retinal neovascularisation and has made anti-VEGF therapy an alternative treatment for PDR, as shown in Figure 6. There has been increasing evidence from clinical trials that demonstrates that anti-VEGF injections are a safe and effective treatment for PDR over at least two years. The Diabetic 
Retinopathy Clinical Research (DRCR) Network and CLARITY studies show that there was no statistically significant visual acuity difference between the anti-VEGF (Ranibizumab and Aflibercept) and PRP groups after two years [104,105]. Different studies showed a better visual acuity, lower incidence of DME, less visual field reduction, and lower number of vitrectomies due to complications secondary to retinopathy in patients treated with anti-VEGF vs. PRP, but the disadvantage is that it presents a shorter-lasting effect of the treatment and requires more visits [106].

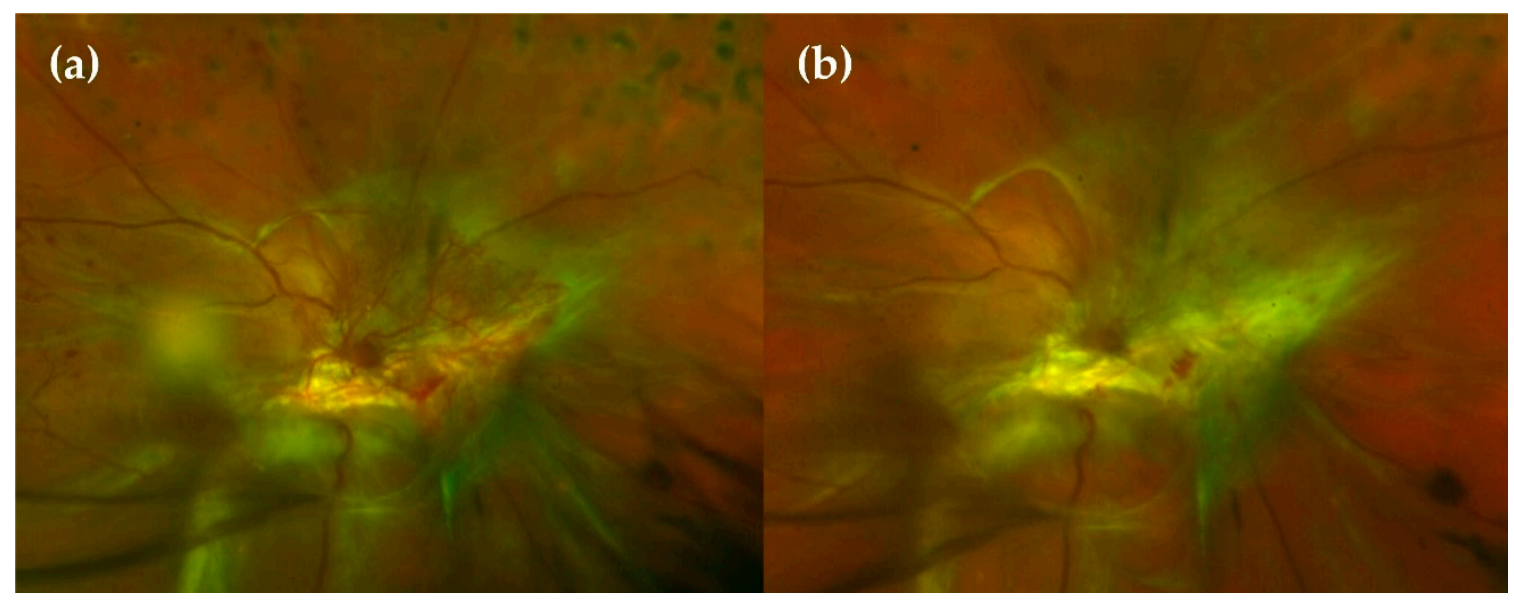

Figure 6. Anti-VEGF injection effect. (a) Papillary neovascularisation in a PDR eye before an anti-VEGF injection. (b) Clear regression of neovessels 3 days after the anti-VEGF injection.

In 2018, the PACORES study revealed a synergistic effect when combining PRP with anti-VEGF, and it concluded that the treatment with ranibizumab + PRP is more effective than PRP monotherapy for neovascularisation regression [107]. These results suggest that intravitreal anti-VEGF therapy may be a viable alternative or adjunct to PRP for the treatment of eyes with PDR over at least two years. However, in clinical practice, antiVEGF therapy for PDR presents some barriers that hinder the correct management of the disease; follow-up frequency, number of anti-VEGF injections, treatment costs and patients' preference must be considered in each case [108]. The five-year retention rate, despite maximal efforts in the DRCR Retina Network protocol, was only 66\% [109]. In one large, retrospective cohort study of patients with PDR, the follow-up absence over a four-year period was 584 out of 2302 patients (25.4\%) [110]. Eyes with PDR only treated with intravitreal anti-VEGF presented worse anatomic and functional outcomes after the lack of follow-up for more than six months compared with eyes treated with PRP [111].

Anti-VEGF therapy has not been shown to improve retinal perfusion and may not prevent the nonperfusion progression in a diabetes-related eye disease. After the cessation of anti-VEGF therapy, recurrent neovascularisation can cause significant loss of visual acuity due to tractional retinal detachment or neovascular glaucoma [112].

The use of anti-VEGF in monotherapy to treat PDR requires exhaustive monitoring. Performing PRP, especially on eyes with clear ischaemic areas, reduces VEGF release in a sustained and lasting way. The synergistic effect of the anti-VEGF and PRP combination favours neovascularisation regression. In the case of DME with PDR, monotherapy with anti-VEGF is a good option, once the neovascularisation has been stabilised; if a new treatment is required, a re-evaluation with anti-VEGF or PRP would be the appropriate procedure [113].

\subsection{Clinically Significant Macular Oedema (CSME)}

Focal laser photocoagulation has been the standard treatment for eyes with CSME. The early treatment diabetic retinopathy study (ETDRS) showed that focal or grid laser photocoagulation reduces the risk of further vision loss in patients with CSME and it has 
been proposed as a preferred treatment for CSME [114,115]. Intravitreal triamcinolone started to be used in the 2000s as a treatment for DME. In 2008, the DRCR Network showed that laser photocoagulation was superior to triamcinolone intravitreal therapy for DME treatment [116]. The "anti-VEGF age for DME treatment" began in 2010, when the DRCR Network showed that intravitreal injections of ranibizumab were better than laser for DME treatment [117]. Subsequently, several trials demonstrated that other anti-VEGF agents (bevacizumab and aflibercept) were also better than laser treatment (Figure 7). The FDA approved the use of aflibercept and ranibizumab as treatments for DME. Bevacizumab is used off-label for this condition. Intravitreal therapy with anti-VEGF is currently the standard of care in the management of eyes with central-involved diabetic macular oedema (CIDME). Numerous clinical trials have shown the advantage when compared with monotherapy or even combination therapy with laser [117-122]. Most eyes with DME respond to anti-VEGF therapy with some degree of anatomical and visual improvement, but in a significant number of eyes, the complete resolution of diabetic macular oedema is not achieved [123]. In clinical practice, an inadequate number of injections is relatively frequent during the followup, mainly due to the difficulty to adhere to monthly visits. A recent five-year follow-up study suggested that vision improved from baseline to five years without protocol-defined treatments after follow-up ended at two years, but vision worsened during the three years of standard care [124].

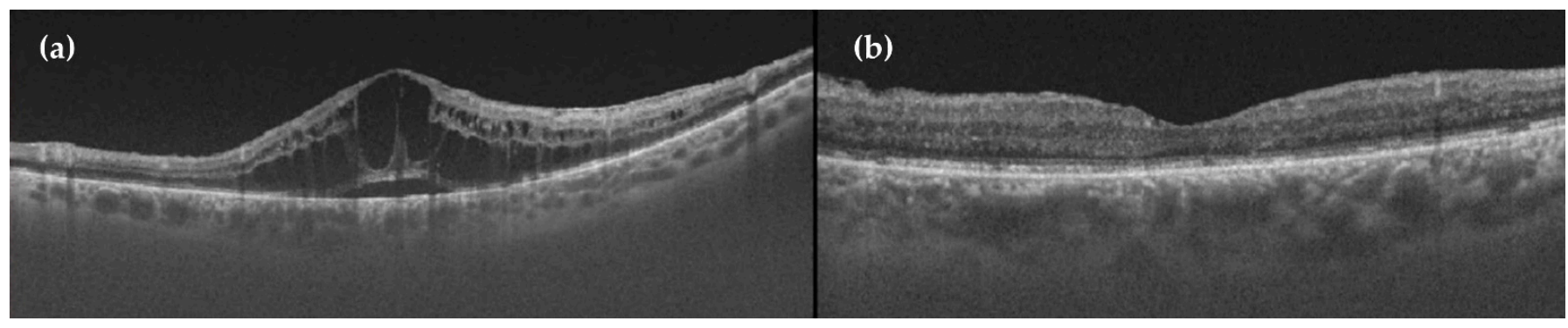

Figure 7. OCT showing the effect of anti-VEGF treatment in diabetic macular oedema (DME). (a) Cystic DME before anti-VEGF injection. (b) Normal macula 1 month after aflibercept (anti-VEGF) injection.

Intravitreal treatment with glucocorticoids for CIDME, such as sustained-release fluocinolone acetonide and dexamethasone implants, has been evaluated in multiple studies and has proved to be effective in reducing retinal thicknesses and in improving vision. However, intravitreal glucocorticoid treatment increases the risk of cataracts and glaucoma $[125,126]$.

The European Society of Retinal Specialists does not recommend laser photocoagulation for the treatment of DME, and it suggests anti-VEGF treatment as a first-line therapy. Steroids have maintained a role in the management of chronically persistent DME [127].

Antioxidants may play an adjuvant effect to these treatments by down-regulating the expression of VEGF and pro-inflammatory pathways [128]. This concept was studied by Lafuente et al. who assessed the effectiveness of intravitreal ranibizumab combined with a dietary supplement rich in docosahexaenoic acid (DHA) and other antioxidants [129]. They found a significant improvement in the central subfield macular thickness compared to patients who only received ranibizumab. These results are discussed in the next section.

\section{Role of Oral Antioxidant Supplementation}

As shown in Table 2, observation and systemic risk factor control are the current treatments for DR patients until severe NPDR, PDR or DME develops. Consequently, physicians and researchers should focus their attention on preventing DR progression as the best tool for avoiding the DR-related loss of vision and blindness; in vitro and animal studies indicate that the pathophysiological pathways of DR, inflammation, neurodegeneration and vasculopathy could be alleviated by nutraceuticals [130]. 
It is postulated that antioxidants inhibit abnormal metabolism and slow DR progression by inhibiting the production of ROS, neutralising free radicals and augmenting the antioxidant defence system [10,131-133]. The role of oral antioxidants has provided promising results in other retinal diseases, such as age-related macular degeneration (AMD) $[134,135]$, but studies with antioxidant supplements have not yet convinced the scientific community to include them as a routine treatment for DR patients.

Oral supplementation with natural antioxidants carries the great advantage of being a noninvasive treatment with presumably no harmful effects [130]. A pending challenge is to determine whether it is an effective treatment for diabetic retinopathy and to identify which agents would be most appropriate to treat these individuals.

The oxidation process starts with the generation of free radicals. The subsequent damage derives from the interaction of those molecules both with polyunsaturated fatty acids, essential elements of the cell membranes, but also with DNA, proteins and other lipids [136]. Depending on the mechanism of action, among antioxidants, we can distinguish enzymatic agents and nonenzymatic substances.

- Enzymatic antioxidants The enzymatic agents accomplish their antioxidant activity by disintegrating and removing free radicals. These are intrinsic intracytosolic enzymes (catalase, superoxide dismutase, glutathione peroxidase and peroxiredoxin) that carry chemical reactions in the presence of several cofactors, such as coenzyme Q10 (ubiquinone), copper $(\mathrm{Cu})$, manganese $(\mathrm{Mn})$, zinc $(\mathrm{Zn})$ or selenium (Se). These cofactors have been added to oral supplementation to promote the inherent mechanisms of auto-defence in the cells [136-138].

- Nonenzymatic antioxidants The nonenzymatic agents act at a second level, disrupting the free radical chain reactions. The majority of them can be extracted from natural sources (plants and fruits), and the following categories are included within this group $[130,136]$ :

- Vitamins: C, E and A.

- Polyphenols

- Flavonoids: large group of agents including flavonols, flavones, flavanones, flavanols (example: pycnogenol containing catechin and epicatechin), anthocyanins, isoflavonoids, homoisoflavonoids and chalcones.

- Nonflavonoids

- Hydroxycinnamic acids: curcumin.

- Stilbenes: resveratrol and pterostilbene.

- Carotenoids: lutein, zeaxanthin, crocin and crocetin.

- Others Alpha-lipoic acid [139], omega-3 polyunsaturated fatty acids [140], calcium dobesilate [141], Asiatic acid, extracts of Gingkgo biloba, turmeric root. Formulae containing different blends of the mentioned agents have been commercialised and used as in ophthalmologic pathologies $[7,142,143]$. Among them, Nutrof Omega ${ }^{\circledR}$, Brudy Retina ${ }^{\circledR}$, Diaberet ${ }^{\circledR}$ and Vitalux Forte ${ }^{\circledR}$ have been tested in patients suffering from DR. Divfuss ${ }^{\circledR}$ was specifically developed for the Diabetes Visual Function Supplement Study [144]. Their composition and effects are discussed later. From them, Diaberet ${ }^{\circledR}$ and Vitalux Forte ${ }^{\circledR}$ are no longer available and their formulae have been updated to Visucomplex Plus ${ }^{\circledR}$ and Vitalux Plus ${ }^{\circledR}$ by the corresponding laboratories. Is it time to include oral antioxidants in the daily management of DR patients? In order to answer this question, a systematic review of studies on antioxidant oral supplementation in DR patients is presented.

\subsection{Methods}

As DR is a chronic pathology affecting millions of people around the world, only experimental, antioxidant supplementation studies on humans, with a follow-up of six or more months, comprising thirty or more DR patients (the value of normal distribution) have been included. Only studies in English, Spanish or French were included. 
Inclusion and exclusion criteria, searches and excluded studies are presented in Supplementary File S1.

\subsection{Results}

After reviewing the abstracts of the 125 initial results by two different researchers, 15 studies were finally included: one case-control observational study [145] and 14 RCTs $[129,144,146-157]$. The studies included are described in Table 3.

Three of the 15 reviewed studies recruited T1DM patients [144,147,157], while 14 recruited T2DM individuals. The clinical profile varied from diabetics without retinopathy to diabetics with mild-to-moderate NPDR. None of the studies included severe NPDR or PDR. Five studies enlisted patients presenting DME $[129,147,149,151,156]$. Follow-up periods varied from six to sixty months.

The variables analysed were:

1. Clinical variables DR onset or progression DME onset or progression Best corrected visual acuity (BCVA) improvement Central macular thickness (CMT) changes Retinal nerve fiber layer (RNFL) thickness changes Retinal blood flow changes Number of Ranibizumab intravitreal injections required

2. Functional variables Retinal sensitivity (dB) Contrast sensitivity Glare sensitivity Macular pigment ocular density (MPOD)

3. Biochemical variables $\mathrm{HbA1c} \%$ values High-density lipoprotein (HDL)/Low-density lipoprotein (LDL)/total cholesterol/triglyceride levels Lipid peroxidation products levels Plasma total antioxidant capacity ROS levels Interleukin 6 (IL-6) plasma levels Microalbuminuria Creatinine clearance

\subsection{Discussion}

\subsubsection{Clinical Variables Results}

The clinical variables depended on subjective evaluation. Four studies analysed the influence of antioxidant supplementation on DR onset or the degree of DR progression [145, $146,151,153]$. Three of them found a significant delay in DR progression in patients receiving Nutrof Omega ${ }^{\circledR}$ or grape seed proanthocyanidins extract (GSPE) supplementation, with follow-up periods of at least 12 months [145,146,151]. The group of Haritoglou et al. examined the onset of DME, basing the diagnosis on a funduscopic evaluation according to the ETDRS criteria, as an OCT device was not available at all the centres. They found no differences between supplemented patients and controls after 24 months of follow-up [154]. Finally, the group of Bursell et al. utilised fluorescein angiography to analyse the retinal blood flow in T1DM patients, and they observed a significant increase in the Vitamin E-supplemented group [157].

As for the quantitative variables, four of the eight trials evaluating CMT changes encountered a significant decrease in macular thickness, with follow-up periods ranging from 6 to 36 months, in patients supplemented with Crocin $15 \mathrm{mg}$ [147], Brudyretina ${ }^{\circledR}[129,149]$ and Diaberet ${ }^{\circledR}$ tablets [152]. Nevertheless, it must be taken into account that the patients included in the studies by Lafuente et al. [129,149] received Ranibizumab injections and Brudyretina ${ }^{\circledR}$ capsules simultaneously; consequently, the improvement cannot be directly assigned to the antioxidant administration.

Similarly, one study reported a significant reduction in the total RNFL thickness [151]. However, this change only affected left eyes and, therefore, it could be considered as a casual finding.

Despite these positive results, it is important to emphasise that none of the studies included in this review were able to prove significant changes in BCVA. 
Table 3. Studies of antioxidant supplementation in patients with diabetic retinopathy included in our review.

\begin{tabular}{|c|c|c|c|c|c|c|c|c|}
\hline $\begin{array}{c}\text { Author/Year/ } \\
\text { Country/Reference }\end{array}$ & Study & Study Focus & $\begin{array}{c}\text { Antioxidant } \\
\text { Composition per Pill }\end{array}$ & $\begin{array}{l}\text { Trade Name } \\
\text { Dose }\end{array}$ & $\begin{array}{c}\text { N per Group: } \\
\text { Supplemented (S) } \\
\text { and Control (C). } \\
\text { Mean Age (Years) }\end{array}$ & $\begin{array}{l}\text { Follow-Up Time } \\
\text { in Months }\end{array}$ & Clinical Findings & $\begin{array}{l}\text { Biochemical } \\
\text { Findings }\end{array}$ \\
\hline $\begin{array}{l}\text { Sanz-González } \\
2020 \\
\text { Spain } \\
\text { [145] }\end{array}$ & Case-control study & $\begin{array}{l}\text { Type } 2 \text { DM with and } \\
\text { without DR }\end{array}$ & $\begin{array}{l}\text { Oil as a source of PUFAs: } \\
400 \mathrm{mg} \\
\text { Omega-3 }(\omega 3) \text { : DHA } \\
140 \mathrm{mg} \\
\text { Vitamin C } 80 \mathrm{mg} \\
\text { Vitamin D } 5 \mu \mathrm{g} \\
\text { Vitamin B } 20.1 \mathrm{mg} \\
\text { Vitamin E } 12 \mathrm{mg} \\
\text { Lutein } 6 \mathrm{mg} \\
\text { Zeaxanthin } 0.3 \mathrm{mg} \\
\text { Glutathione } 1 \mathrm{mg} \\
\text { Hydroxytyrosol } 0.75 \mathrm{mg} \\
\text { Zinc } 7.5 \mathrm{mg} \\
\text { Copper } 1 \mathrm{mg} \\
\text { Selenium } 55 \mu \mathrm{\mu g} \\
\text { Manganese } 2 \mathrm{mg} \\
\text { Dosage }=1 \text { tablet } / \text { day: } \\
\text { Supplement or Placebo }\end{array}$ & $\begin{array}{l}\text { Nutrof Omega }{ }^{\circledR} \\
\text { (Thea SA, } \\
\text { (Barcelona, Spain) }\end{array}$ & $\begin{array}{l}\mathrm{N}=365 \\
\text { 225 T2DM } \\
\text {-With DR: } 100 \\
\text {-Without DR: } 125 \\
\text { 140 healthy controls } \\
\text { Mean Age: } \\
\text { T2DM: 60 } \\
\text { Controls: } 55\end{array}$ & 38 & $\begin{array}{l}\text { The placebo group } \\
\text { was more } \\
\text { representative in } \\
\text { subjects with T2DM } \\
\text { in whom DR } \\
\text { progressed. } \\
\text { NS differences in } \\
\text { IOP and CMT }\end{array}$ & $\begin{array}{l}\text { The A / } \omega 3 \text { regime } \\
\text { significantly reduced } \\
\text { the pro-oxidants } \\
(p<0.05) \text { and } \\
\text { augmented the } \\
\text { antioxidants } \\
(p<0.05) .\end{array}$ \\
\hline $\begin{array}{l}\text { Moon } \\
2019 \\
\text { Korea } \\
{[146]}\end{array}$ & $\begin{array}{l}\text { Randomised } \\
(1: 2: 2), \\
\text { double-blind } \\
\text { controlled trial }\end{array}$ & $\begin{array}{l}\text { Type } 2 \text { DM with } \\
\text { NPDR } \\
40-80 \text { y.o. } \\
\text { AV }>0.5 \\
\text { Without laser or } \\
\text { intravitreal therapy } \\
\text { or intraocular } \\
\text { surgery in the } \\
\text { previous } 6 \text { months }\end{array}$ & $\begin{array}{l}\text { S group 1: } 50 \mathrm{mg} \text {-Grape } \\
\text { seed proanthocyanidins } \\
\text { extracts (GSPE) (Vitis } \\
\text { vinifera extract) } \\
\text { S group 2: } 250 \mathrm{mg} \text { of } \\
\text { calcium dobesilate (CD) } \\
\text { C group. }\end{array}$ & $\begin{array}{l}\text { GSPE: } \\
\text { Entelon (Hanlim } \\
\text { Pharm, Seoul, } \\
\text { South Korea) } \\
\text { CD: } \\
\text { Doxium (Ilsung } \\
\text { Pharm, Seoul, } \\
\text { South Korea). }\end{array}$ & $\begin{array}{l}\mathrm{N}=86 \\
3 \text { tablets } 3 \text { times } \\
\text { daily } \\
\text { S1: GSPE (150 } \\
\text { mg/day): } 32 \\
\text { S2: CD (750 } \\
\text { mg/day): } 35 \\
\text { Placebo: } 19\end{array}$ & 12 & $\begin{array}{l}\text { Hard exudates } \\
\text { severity } \\
\text { improvement: } \\
\text { higher in GSPE } \\
(43.9 \%) \text { vs. CD } \\
(14.29 \%) \text { and vs. } \\
\text { placebo }(8 \%) \\
(0.0007) \\
\text { NS differences } \\
\text { between OCT } \\
\text { parameters (CMT, } \\
\text { TVM) } \\
\text { GSPE TVM } \\
\text { significantly } \\
\text { decreases with } \\
\text { respect to baseline. }\end{array}$ & $\begin{array}{l}\text { NS differences with } \\
\text { regard to vital signs } \\
\text { and laboratory } \\
\text { results between } \\
\text { groups. }\end{array}$ \\
\hline
\end{tabular}


Table 3. Cont.

\begin{tabular}{|c|c|c|c|c|c|c|c|c|}
\hline $\begin{array}{c}\text { Author/Year/ } \\
\text { Country/Reference }\end{array}$ & Study & Study Focus & $\begin{array}{c}\text { Antioxidant } \\
\text { Composition per Pill }\end{array}$ & $\begin{array}{l}\text { Trade Name } \\
\text { Dose }\end{array}$ & $\begin{array}{c}\text { N per Group: } \\
\text { Supplemented (S) } \\
\text { and Control (C). } \\
\text { Mean Age (Years) }\end{array}$ & $\begin{array}{l}\text { Follow-Up Time } \\
\text { in Months }\end{array}$ & Clinical Findings & $\begin{array}{l}\text { Biochemical } \\
\text { Findings }\end{array}$ \\
\hline $\begin{array}{l}\text { Lafuente } \\
2019 \\
\text { Spain } \\
\text { [129] }\end{array}$ & $\begin{array}{l}\text { Randomised } \\
\text { Single-Blind } \\
\text { Controlled } \\
\text { Trial }\end{array}$ & $\begin{array}{l}\text { T2DM adults with } \\
\text { decreased vision due } \\
\text { to central-involved } \\
\text { DME }\end{array}$ & $\begin{array}{l}\text { Omega-3 Fatty Acids } \\
\text { DHA } 350 \mathrm{mg} \\
\text { EPA } 42.5 \mathrm{mg} \\
\text { DPA } 30 \mathrm{mg} \\
\text { Vitamin C } 26.7 \mathrm{mg} \\
\text { Vitamin E } 4 \mathrm{mg} \\
\text { B vitamins } 7.3 \mathrm{mg} \\
\text { Lutein } 3 \mathrm{mg} \\
\text { Zeaxanthin } 0.3 \mathrm{mg} \\
\text { Glutathione } 2 \mathrm{mg} \\
\text { Zinc } 1.66 \mathrm{mg} \\
\text { Copper } 0.16 \mathrm{mg} \\
\text { Selenium } 9.16 \mathrm{\mu g} \\
\text { Manganese } 0.33 \mathrm{mg}\end{array}$ & $\begin{array}{l}\text { Brudyretina }{ }^{\circledR} 1.5 \mathrm{~g} \\
\text { (Brudy Lab S.L } \\
\text { Barcelona, Spain) } \\
3 \text { capsules of } 1.5 \mathrm{~g} \\
\text { once daily }\end{array}$ & $\begin{array}{l}\mathrm{N}=55 \text { (69 eyes) } \\
\mathrm{S}+\text { Ranibizumab * } \\
\mathrm{n}=26 \text { (31 eyes) } \\
\mathrm{C}: \text { Only } \\
\text { Ranibizumab* } \\
\mathrm{n}=29 \text { (38 eyes) } \\
\text { All patients with } \\
\text { four monthly doses } \\
\text { of ranibizumab } \\
\text { followed by pro re } \\
\text { nata basis. }\end{array}$ & 36 & $\begin{array}{l}\text { VA: NS difference in } \\
\text { ETDRS letters. } \\
\text { Gains of }>5 \text { and }>10 \\
\text { letters significantly } \\
\text { higher in S group. } \\
\text { CMT: Significant } \\
\text { decrease in S group } \\
\text { vs. C group } \\
(275 \pm 50 \mu \mathrm{m} \text { vs. } \\
310 \pm 97 \mu \mathrm{m}) \\
\text { Number of } \\
\text { Ranibizumab } \\
\text { injections: NS } \\
\text { differences between } \\
\text { groups. }\end{array}$ & $\begin{array}{l}\text { Significant } \\
\text { differences in HbA1c, } \\
\text { plasma total } \\
\text { antioxidant capacity } \\
\text { values, erythrocyte } \\
\text { DHA content and } \\
\text { IL-6 levels in favour } \\
\text { of S group. }\end{array}$ \\
\hline $\begin{array}{l}\text { Sepahi } \\
2018 \\
\text { Iran } \\
\text { [147] }\end{array}$ & $\begin{array}{l}\text { Phase } 2 \\
\text { randomised, } \\
\text { double-blind, } \\
\text { placebo-controlled } \\
\text { trial. }\end{array}$ & $\begin{array}{l}\text { Refractory to } \\
\text { conventional DME } \\
\text { therapy in type } 1 \text { or } \\
2 \text { diabetes } \\
\text { Refractory therapy } \\
\text { including: macular } \\
\text { photocoagulation } \\
\text { and intravitreal } \\
\text { injection of } \\
\text { bevacizumab with or } \\
\text { without } \\
\text { triamcinolone }\end{array}$ & $\begin{array}{l}\text { S1: Crocin tablet } 15 \mathrm{mg} \\
\text { S2: Crocin tablet } 5 \mathrm{mg}\end{array}$ & $\begin{array}{l}\text { Crocin tablet } \\
\text { Pharmaceutical } \\
\text { laboratory of } \\
\text { School of } \\
\text { Pharmacy, } \\
\text { Mashhad } \\
\text { University of } \\
\text { Medical Science, } \\
\text { Mashhad, Iran } \\
1 \text { tablet per day (15 } \\
\text { mg, } 5 \text { mg or } \\
\text { placebo) }\end{array}$ & $\begin{array}{l}\mathrm{N}=60 \text { patients }(101 \\
\text { eyes) } \\
\text { S 1: } 20 \text { (33 eyes) } \\
\text { S 2: } 20 \text { (34 eyes) } \\
\text { C: } 20 \text { ( } 34 \text { eyes) } \\
\text { Age: } \\
\text { 41-82 }\end{array}$ & $\begin{array}{l}\text { Supplementation: } \\
3 \\
\text { Follow-up: } 6\end{array}$ & $\begin{array}{l}\text { VA: } \\
\text { LogMAR: } \\
\text { S1 significantly } \\
\text { improved compared } \\
\text { to S2 }(p<0.05) \text { and } \\
\text { to C }(p=0.02) \text {. } \\
\text { CMT: } \\
\text { S1 significantly } \\
\text { improved compared } \\
\text { to S2 }(p<0.05) \text { and } \\
\text { to C }(p=0.005) \text {. } \\
\text { S2 NS improvement } \\
\text { compared to C. }\end{array}$ & $\begin{array}{l}\text { HbA1c and FBS: S1 } \\
\text { and S2 significantly } \\
\text { better than C. }\end{array}$ \\
\hline $\begin{array}{l}\text { Zhang } \\
2017 \\
\text { China } \\
{[148]}\end{array}$ & $\begin{array}{l}\text { Randomised, } \\
\text { double-blind, } \\
\text { placebo-controlled } \\
\text { trial }\end{array}$ & $\begin{array}{l}\text { NPDR mild or } \\
\text { moderate stages } \\
\text { Type } 2 \text { diabetes } \\
\text { Exclusion criteria: } \\
\text { DME, other eye } \\
\text { disorders other than } \\
\text { mild or moderate } \\
\text { NPDR }\end{array}$ & $\begin{array}{l}\text { Lutein } 10 \mathrm{mg} \\
\text { Placebo capsule }\end{array}$ & $\begin{array}{l}\text { Lutein } 10 \mathrm{mg} 1 \\
\text { capsule once a day } \\
\text { (1 capsule of } \\
\text { placebo once a day } \\
\text { if C) } \\
\text { Lutein } \\
\text { Pharmaceutical Co } \\
\text { Ltd. (Guangzhou, } \\
\text { China) }\end{array}$ & $\begin{array}{l}\mathrm{N}=30 \text { patients } \\
\mathrm{S}: 15 \\
\mathrm{C}: 15 \\
\text { Mean age: } \\
\text { 60.2., SD: } 10.3\end{array}$ & 9 & $\begin{array}{l}\text { VA: slight NS } \\
\text { improvement in S } \\
(p=0.11) \\
\text { Contrast sensitivity: } \\
\text { S: significant } \\
\text { increase in } 3 \text { cycles }{ }^{\circ} \\
\text { by } 0.16(p=0.02) \\
\text { ANOVA analysis } \\
\text { showed differences } \\
\text { between } S \text { and C. NS } \\
\text { in } 6.12 \text { and } 36 \\
\text { cycles } /^{\circ} \text {. } \\
\text { Glare sensitivity: NS } \\
\text { differences. }\end{array}$ & \\
\hline
\end{tabular}


Table 3. Cont.

\begin{tabular}{|c|c|c|c|c|c|c|c|c|}
\hline $\begin{array}{c}\text { Author/Year/ } \\
\text { Country/Reference }\end{array}$ & Study & Study Focus & $\begin{array}{c}\text { Antioxidant } \\
\text { Composition per Pill }\end{array}$ & $\begin{array}{l}\text { Trade Name } \\
\text { Dose }\end{array}$ & $\begin{array}{c}\text { N per Group: } \\
\text { Supplemented (S) } \\
\text { and Control (C). } \\
\text { Mean Age (Years) }\end{array}$ & $\begin{array}{l}\text { Follow-Up Time } \\
\text { in Months }\end{array}$ & Clinical Findings & $\begin{array}{l}\text { Biochemical } \\
\text { Findings }\end{array}$ \\
\hline $\begin{array}{l}\text { Lafuente } \\
2017 \\
\text { Spain } \\
{[149]}\end{array}$ & $\begin{array}{l}\text { Randomised } \\
\text { Single-Blind } \\
\text { Controlled } \\
\text { Trial }\end{array}$ & $\begin{array}{l}\text { Type } 2 \text { diabetes } \\
\text { adults with } \\
\text { decreased vision due } \\
\text { to central-involved } \\
\text { DME. }\end{array}$ & $\begin{array}{l}\text { Omega-3 Fatty Acids } \\
\text { DHA } 350 \mathrm{mg} \\
\text { EPA } 42.5 \mathrm{mg} \\
\text { DPA } 30 \mathrm{mg} \\
\text { Vitamin C } 26.7 \mathrm{mg} \\
\text { Vitamin E } 4 \mathrm{mg} \\
\text { B vitamins } 7.3 \mathrm{mg} \\
\text { Lutein } 3 \mathrm{mg} \\
\text { Zeaxanthin } 0.3 \mathrm{mg} \\
\text { Glutathione } 2 \mathrm{mg} \\
\text { Zinc } 1.66 \mathrm{mg} \\
\text { Copper } 0.16 \mathrm{mg} \\
\text { Selenium } 9.16 \mathrm{\mu g} \\
\text { Manganese } 0.33 \mathrm{mg}\end{array}$ & $\begin{array}{l}\text { Brudyretina }{ }^{\circledR} 1.5 \mathrm{~g} \\
\text { (Brudy Lab S.L } \\
\text { Barcelona, Spain) } \\
3 \text { capsules of } 1.5 \mathrm{~g} \\
\text { once daily }\end{array}$ & $\begin{array}{l}\mathrm{N}=76 \text { eyes } \\
\mathrm{S}+\text { Ranibizumab * } \\
\mathrm{n}=34 \\
\mathrm{C}: \text { Only } \\
\text { Ranibizumab* } \\
\mathrm{n}=42 \\
\text { All patients with } \\
\text { four monthly doses } \\
\text { of ranibizumab } \\
\text { followed by pro re } \\
\text { nata basis. }\end{array}$ & 24 & $\begin{array}{l}\text { VA: NS difference in } \\
\text { ETDRS letters. } \\
\text { Gains of }>5 \text { letters } \\
\text { significantly higher } \\
\text { in S group } \\
(p=0.044), \text { NS for } \\
\text { gains of }>10 \text { letters. } \\
\text { CMT: Significant } \\
\text { decrease in S group } \\
(95 \% \text { CI } 7.20-97.656 \text {; } \\
p=0.024) \\
\text { Number of } \\
\text { Ranibizumab } \\
\text { injections: NS } \\
\text { differences between } \\
\text { groups. }\end{array}$ & $\begin{array}{l}\text { Significant increase } \\
\text { in TAC (total } \\
\text { antioxidative } \\
\text { capacity) in S group } \\
(p<0.001) \\
\text { Significant reduction } \\
\text { in the erythrocyte } \\
\text { membrane content of } \\
\omega-6 \text { arachidonic acid } \\
\text { in the S group } \\
(p<0.05) \\
\text { NS differences in } \\
\text { HbA1c levels }\end{array}$ \\
\hline $\begin{array}{l}\text { Rodriguez-Carrizalez } \\
2016 \\
\text { Mexico } \\
{[150]}\end{array}$ & $\begin{array}{l}\text { Randomised, } \\
\text { controlled, phase } \\
\text { IIa clinical trial }\end{array}$ & $\begin{array}{l}\text { T2DM with NPDR, } \\
\text { but without DME }\end{array}$ & $\begin{array}{l}\text { S1: } \\
\text { Ubiquinone } 400 \mathrm{mg} \\
\text { Dosage } 1 \text { tablet/day } \\
\text { S2: } \\
\text { Vitamin C } 180 \mathrm{mg} \\
\text { Vitamin E } 30 \mathrm{mg} \\
\text { Lutein } 10 \mathrm{mg} \\
\text { Astaxanthin } 4 \mathrm{mg} \\
\text { Zeaxanthin } 1 \mathrm{mg} \\
\text { Zinc } 20 \mathrm{mg} \\
\text { Dosage } 1 \text { tablet/day } \\
\text { C: } \\
\text { Placebo tablet }\end{array}$ & $\begin{array}{l}\text { Noncommer- } \\
\text { cialised } \\
\text { supplement }\end{array}$ & $\begin{array}{l}\mathrm{N}=60 \text { patients } \\
\text { S1: } \mathrm{N}=20 \\
\text { S2: } \mathrm{N}=20 \\
\mathrm{C}: \mathrm{N}=20 \\
\text { Mean age } \\
\text { S1: } 58.5 \pm 1.9 \\
\text { S2: }: 2.1 \pm 1.1 \\
\text { C: } 57.8 \pm 1.9\end{array}$ & 6 & VA: NS changes & $\begin{array}{l}\text { S1 and S2 } \\
\text { Significant decrease } \\
\text { in lipid peroxidation } \\
\text { products, NO } \\
\text { metabolites, catalase } \\
\text { and glutathione } \\
\text { peroxidase } \\
(p<0.0001) \\
\text { Increased TAC } \\
(p<0.0001) \\
V s \text {. C group } \\
\text { NS changes in } \\
\text { HbA1c\%, cholesterol } \\
\text { and triglyceride } \\
\text { levels between } \\
\text { groups }\end{array}$ \\
\hline
\end{tabular}


Table 3. Cont.

\begin{tabular}{|c|c|c|c|c|c|c|c|c|}
\hline $\begin{array}{c}\text { Author/Year/ } \\
\text { Country/Reference }\end{array}$ & Study & Study Focus & $\begin{array}{c}\text { Antioxidant } \\
\text { Composition per Pill }\end{array}$ & $\begin{array}{l}\text { Trade Name } \\
\text { Dose }\end{array}$ & $\begin{array}{c}\text { N per Group: } \\
\text { Supplemented (S) } \\
\text { and Control (C). } \\
\text { Mean Age (Years) }\end{array}$ & $\begin{array}{l}\text { Follow-Up Time } \\
\text { in Months }\end{array}$ & Clinical Findings & $\begin{array}{l}\text { Biochemical } \\
\text { Findings }\end{array}$ \\
\hline $\begin{array}{l}\text { Chous } \\
2016 \\
\text { USA } \\
\text { [144] }\end{array}$ & $\begin{array}{l}\text { Randomised } \\
\text { controlled } \\
\text { clinical trial }\end{array}$ & $\begin{array}{l}\text { T1 or T2DM without } \\
\text { DR or with } \\
\text { mild-to-moderate } \\
\text { NPDR without } \\
\text { CSME }\end{array}$ & $\begin{array}{l}\text { S: } \\
\text { Vitamin C } 60 \mathrm{mg} \\
\text { Vitamin D3 } 50 \mathrm{mg} \\
\text { Vitamin E } 40 \mathrm{mg} \\
\alpha \text {-Lipoic acid } 150 \mathrm{mg} \\
\text { Coenzyme Q10 } 20 \mathrm{mg} \\
\text { Omega-3 Fatty Acids } \\
\text { EPA } 128 \mathrm{mg} \\
\text { DHA } 96 \mathrm{mg} \\
\text { Zeaxanthin } 8 \mathrm{mg} \\
\text { Lutein } 4 \mathrm{mg} \\
\text { Zinc oxide } 15 \mathrm{mg} \\
\text { Benfotiamine } \\
\text { N-acetyl cysteine } \\
\text { Grape seed extract } \\
\text { Resveratrol } \\
\text { Turmeric root Extract } \\
\text { green tea leaf } \\
\text { Pycnogenol } \\
\text { (Not specified mg) } \\
\text { Dosage = 2 tablets/day } \\
\text { C: Placebo tablet }\end{array}$ & $\begin{array}{l}\text { DiVFuSS }^{\circledR} \\
\text { (ZeaVision, LLC, }_{\text {Chesterfield, MO, }} \\
\text { USA) }\end{array}$ & $\begin{array}{l}\mathrm{N}=67 \text { patients } \\
\mathrm{S}: \mathrm{N}=39 \\
\mathrm{C}: \mathrm{N}=28 \\
\text { Mean age } \\
\mathrm{S}: 53.5 \pm 14.6 \\
\mathrm{C}: 59.7 \pm 10.3\end{array}$ & 6 & $\begin{array}{l}\text { VA: NS changes } \\
\text { CMT: NS changes } \\
\text { RNFL thickness: NS } \\
\text { changes } \\
\text { Contrast sensitivity, } \\
\text { colour error } \\
\text { Score, visual field } \\
\text { mean sensitivity and } \\
\text { MPOD: significant } \\
27 \% \text { improvement in } \\
\text { the S group vs. } 2 \% \text { in } \\
\text { the C group. } \\
\text { ( } p \text { values ranging } \\
\text { from 0.008 to } \\
<0.0001) \text {. } \\
\text { MPOD (macular } \\
\text { pigment optical } \\
\text { density) }\end{array}$ & $\begin{array}{l}\text { NS changes in } \\
\text { HbA1c, total } \\
\text { cholesterol or TNF- } \alpha \\
\text { between the groups }\end{array}$ \\
\hline $\begin{array}{l}\text { Roig-Revert } \\
2015 \\
\text { Spain } \\
{[151]}\end{array}$ & $\begin{array}{l}\text { Randomised, } \\
\text { prospective, } \\
\text { multicentre study }\end{array}$ & $\begin{array}{l}\text { T2DM } \\
\text { Group 1: NPDR } \\
\pm \text { DME } \\
\text { Group 2: Diabetic } \\
\text { patients without DR } \\
\text { Healthy subjects }\end{array}$ & $\begin{array}{l}\text { S: } \\
\text { Vitamin C } 80 \mathrm{mg} \\
\text { Vitamin D } 5 \mu \mathrm{gg} \\
\text { Vitamin B 20.1 mg } \\
\text { Vitamin E } 12 \mathrm{mg} \\
\text { Omega-3: DHA } 140 \mathrm{mg} \\
\text { Lutein } 6 \mathrm{mg} \\
\text { Zeaxanthin } 0.3 \mathrm{mg} \\
\text { Glutathione } 1 \mathrm{mg} \\
\text { Hydroxytyrosol } 0.75 \mathrm{mg} \\
\text { Zinc } 7.5 \mathrm{mg} \\
\text { Copper } 1 \mathrm{mg} \\
\text { Selenium } 55 \mu \mathrm{g} \\
\text { Manganese } 2 \mathrm{mg} \\
\text { Dosage = } 1 \text { tablet/day } \\
\text { C: no placebo capsule }\end{array}$ & $\begin{array}{l}\text { Nutrof Omega } \\
\text { (Thea SA, } \\
\text { (Barcelona, Spain) }\end{array}$ & $\begin{array}{l}\mathrm{N}=208 \text { patients } \\
\text { Group 1 DM DR }+ \\
(\mathrm{N}=62) \\
\mathrm{S}(\mathrm{n}=\text { not specified }) \\
\mathrm{C}(\mathrm{n}=\text { not specified }) \\
\text { Group } 2 \text { DM DR- } \\
(\mathrm{N}=68) \\
\mathrm{S}(\mathrm{N}=\text { not specified }) \\
\mathrm{C}(\mathrm{n}=\text { not specified }) \\
\text { Group } 3 \text { Healthy } \\
\text { subjects } \\
(\mathrm{N}=78) \\
\mathrm{S}(\mathrm{n}=\text { not specified }) \\
\mathrm{C}(\mathrm{n}=\text { not specified }) \\
\text { Mean age } \\
\text { DM DR+65.1 } \\
\text { DM DR }-6.3 \pm 10.1\end{array}$ & 18 & $\begin{array}{l}\text { Group } 1 \text { DM DR + } \\
\text { DR progression: } \\
\text { S: } 61 \% \\
\text { C: } 91 \% \\
\text { Group } 2 \text { DM DR- } \\
\text { DR onset: } \\
\text { S: } 9 \% \\
\text { C: } 35 \% \\
\text { RNFLT of the LE } \\
\text { was significantly } \\
\text { reduced in the S } \\
\text { group }(p=0.01)\end{array}$ & $\begin{array}{l}\text { Significant reduction } \\
\text { in TAS in } \\
\text { supplemented } \\
\text { DMDR+ }(p=0.020) \\
\text { Plasma lipid } \\
\text { peroxidation } \\
\text { by-products } \\
\text { significantly } \\
\text { decreased in the } \\
\text { DMDR+ } \\
\text { supplemented group } \\
\text { NS in terms of } \\
\text { HbA1c, HDL/LDL } \\
\text { cholesterol and } \\
\text { triglycerides. }\end{array}$ \\
\hline
\end{tabular}


Table 3. Cont.

\begin{tabular}{|c|c|c|c|c|c|c|c|c|}
\hline $\begin{array}{c}\text { Author/Year/ } \\
\text { Country/Reference }\end{array}$ & Study & Study Focus & $\begin{array}{c}\text { Antioxidant } \\
\text { Composition per Pill }\end{array}$ & $\begin{array}{l}\text { Trade Name } \\
\text { Dose }\end{array}$ & $\begin{array}{c}\text { N per Group: } \\
\text { Supplemented (S) } \\
\text { and Control (C). } \\
\text { Mean Age (Years) }\end{array}$ & $\begin{array}{l}\text { Follow-Up Time } \\
\text { in Months }\end{array}$ & Clinical Findings & $\begin{array}{l}\text { Biochemical } \\
\text { Findings }\end{array}$ \\
\hline $\begin{array}{l}\text { Domanico } \\
2015 \\
\text { Italy } \\
{[152]}\end{array}$ & $\begin{array}{l}\text { Randomised } \\
\text { prospective study }\end{array}$ & $\begin{array}{l}\text { T2DM showing } \\
\text { mild-to-moderate } \\
\text { NPDR, without } \\
\text { CSME or CVRF }\end{array}$ & $\begin{array}{l}\text { Vitamin E } 30 \mathrm{mg} \\
\text { Pycnogenol } 50 \mathrm{mg} \\
\text { Coenzyme Q10 } 20 \mathrm{mg} \\
\text { Dosage = } 1 \text { tablet } / \text { day } \\
\text { C: no placebo capsule }\end{array}$ & $\begin{array}{l}\text { Diaberet }^{\circledR} \\
\text { (Visufarma, Rome, } \\
\text { Italy) }\end{array}$ & $\begin{array}{l}N=68 \text { patients (eyes) } \\
S: N=34 \\
C: N=34 \\
\text { Mean age } \\
S: 58.29 \pm 12.37 \\
C: 62.29 \pm 11.54\end{array}$ & 6 & $\begin{array}{l}\text { CMT: significant } \\
\text { reduction on the S } \\
\text { group } \\
(p<0.01) \\
(-15.44 \mu \mathrm{m},[95 \% \mathrm{CI} \text { : } \\
3.26,27.61])\end{array}$ & $\begin{array}{l}\text { Significant reduction } \\
\text { of ROS levels (free } \\
\text { oxygen radical test) } \\
\text { in the S group } \\
(p<0.001)\end{array}$ \\
\hline $\begin{array}{l}\text { Watanabe } \\
2014 \\
\text { Japan } \\
\text { [153] }\end{array}$ & $\begin{array}{l}\text { Randomised, } \\
\text { prospective } \\
\text { study }\end{array}$ & $\begin{array}{l}\text { T2DM patients } \\
\text { without DR }\end{array}$ & $\begin{array}{l}2.5 \mathrm{~g} \text { of goshajinkigan } \\
\text { extract three times a day, } \\
\text { which included: } \\
4.5 \mathrm{~g} \text { of the compound } \\
\text { extracts of } 10 \text { herbal } \\
\text { medicines: Rehmanniae } \\
\text { radix }(5 \mathrm{~g}) \text {, Achyranthis } \\
\text { radix }(3 \mathrm{~g}) \text {, Corni fructus } \\
(3 \mathrm{~g}), \\
\text { Dioscoreae rhizoma }(3 \mathrm{~g}) \text {, } \\
\text { Hoelen }(3 \mathrm{~g}) \text {, Plantaginis } \\
\text { semen } \\
(3 \mathrm{~g}), \text { Alismatis rhizoma } \\
(3 \mathrm{~g}), \text { Moutan cortex }(3 \mathrm{~g}) \text {, } \\
\text { Cinnamomi cortex }(1 \mathrm{~g}) \\
\text { and heat-processed } \\
\text { Aconiti radix }(1 \mathrm{~g})\end{array}$ & $\begin{array}{l}\text { TJ-107; Tsumura } \\
\text { Co., Tokyo, Japan }\end{array}$ & $\begin{array}{l}N=116 \text { patients } \\
S: N=74 \\
C: N=42 \\
\text { Mean age } \\
\text { S: } 59.4 \pm 7.8 \\
C: 60.9 \pm 7.4\end{array}$ & 60 & $\begin{array}{l}\text { Progression of } \\
\text { retinopathy: No } \\
\text { differences between } \\
\text { S and C. } \\
\text { A total of } 25 \text { patients } \\
\text { had DR at the end of } \\
\text { the study. } \\
17.9 \% \text { in } \\
\text { Goshajinkigan group } \\
20.0 \% \text { in control } \\
\text { group } \\
p=0.816\end{array}$ & $\begin{array}{l}\text { Glycated } \\
\text { haemoglobin } \\
\text { significantly } \\
\text { decreased in the S } \\
\text { group at the 60th } \\
\text { month. Fasting } \\
\text { glucose significantly } \\
\text { decreased in the S } \\
\text { group beginning at } \\
\text { the 36th month. } \\
\text { No differences } \\
\text { between insulin or } \\
\text { oral antidiabetic } \\
\text { medications. }\end{array}$ \\
\hline $\begin{array}{l}\text { Haritoglou } \\
2011 \\
\text { Germany } \\
\text { [154] }\end{array}$ & $\begin{array}{l}\text { Randomised, } \\
\text { prospective, } \\
\text { multicentre, } \\
\text { study }\end{array}$ & $\begin{array}{l}\text { T2DM showing } \\
\text { mild-to-moderate } \\
\text { NPDR in at least one } \\
\text { eye }\end{array}$ & $\begin{array}{l}\text { S: } \\
\alpha \text {-lipoic acid (ALA) } \\
600 \mathrm{mg} \\
\text { Dosage } \\
1 \text { tablet/day } \\
\text { C: placebo tablet }\end{array}$ & $\begin{array}{l}\text { Noncommercialised } \\
\text { supplement }\end{array}$ & $\begin{array}{l}\mathrm{N}:=399 \text { patients } \\
\mathrm{S}:=196 \\
\mathrm{C}:=203 \\
\text { Mean age } \\
\text { S 58.0 } \\
\text { C 57.9 }\end{array}$ & 24 & $\begin{array}{l}\text { CSME debut during } \\
\text { follow-up } \\
\text { S } 26 / 196 \\
\text { C } 30 / 203 \\
\text { NS reduction in } \\
\text { macular oedema } \\
\text { development } \\
(p=0.7108)\end{array}$ & $\begin{array}{l}\text { NS differences in } \\
\text { terms of HbA1c } \\
\text { levels between } \\
\text { groups }\end{array}$ \\
\hline $\begin{array}{l}\text { García-Medina } \\
2011 \\
\text { Spain } \\
\text { [155] }\end{array}$ & $\begin{array}{l}\text { Randomised } \\
\text { prospective study }\end{array}$ & $\begin{array}{l}\text { T2DM with NPDR } \\
\text { but no CSME }\end{array}$ & $\begin{array}{l}\text { S: } \\
\text { Vitamin C } 60 \mathrm{mg} \\
\text { Vitamin E } 10 \mathrm{mg} \\
\text { Lutein } 3 \mathrm{mg} \\
\text { Zinc } 13.5 \mathrm{mg} \\
\text { Copper } 1 \mathrm{mg} \\
\text { Selenium } 10 \mu \mathrm{gg} \\
\text { Manganese } 1 \mathrm{mg} \\
\text { Niacin } 10 \mathrm{mg} \\
\beta \text {-Carotene } 3 \mathrm{mg} \\
\text { Dosage }=2 \text { tablets/day } \\
\text { C: no placebo capsule }\end{array}$ & $\begin{array}{l}\text { Vitalux Forte } \\
\text { (Novartis Pharma } \\
\text { AG Ophthalmics, } \\
\text { Basel, Switzerland) }\end{array}$ & $\begin{array}{l}\mathrm{N}=97 \text { patients } \\
\mathrm{S}: \mathrm{N}=56 \\
\mathrm{C}: \mathrm{N}=41 \\
\text { Mean age } \\
S 53.3 \pm 11.9 \\
C 57.0 \pm 11.4\end{array}$ & 60 & $\begin{array}{l}\text { VA: NS changes } \\
\text { DR degree: } \\
\text { Significant } \\
\text { progression in C } \\
\text { group } \\
(p<0.01) \\
\text { vs. non-significant } \\
\text { progression in } S \\
\text { group }\end{array}$ & $\begin{array}{l}\text { Significant reduced } \\
\text { plasma lipid } \\
\text { peroxidation end } \\
\text { products (MDA) in S } \\
\text { vs. increased in C } \\
\text { group }(p<0.01) \\
\text { Stable TAS in the S } \\
\text { group vs. significant } \\
\text { decrease in C group } \\
(p=0.02)\end{array}$ \\
\hline
\end{tabular}


Table 3. Cont.

\begin{tabular}{|c|c|c|c|c|c|c|c|c|}
\hline $\begin{array}{c}\text { Author/Year/ } \\
\text { Country/Reference }\end{array}$ & Study & Study Focus & $\begin{array}{c}\text { Antioxidant } \\
\text { Composition per Pill }\end{array}$ & $\begin{array}{l}\text { Trade Name } \\
\text { Dose }\end{array}$ & $\begin{array}{l}\text { N per Group: } \\
\text { Supplemented (S) } \\
\text { and Control (C). } \\
\text { Mean Age (Years) }\end{array}$ & $\begin{array}{l}\text { Follow-Up Time } \\
\text { in Months }\end{array}$ & Clinical Findings & $\begin{array}{l}\text { Biochemical } \\
\text { Findings }\end{array}$ \\
\hline $\begin{array}{l}\text { Forte } \\
2011 \\
\text { Italy } \\
{[156]}\end{array}$ & $\begin{array}{l}\text { Randomised } \\
\text { prospective, } \\
\text { interventional, } \\
\text { controlled study }\end{array}$ & $\begin{array}{l}\text { T2DM and } \\
\text { DME without } \\
\text { macular thickening } \\
\text { at OCT }\end{array}$ & $\begin{array}{l}\mathrm{S}= \\
\text { Desmin } 300 \mathrm{mg} \\
\text { Troxerutin } 300 \mathrm{mg} \\
\mathrm{C} \text {. asiatica } 30 \mathrm{mg} \\
\text { Melilotus } 160 \\
\text { Dosage } 1 / \text { day } \\
\mathrm{C} \text { = Placebo capsule }\end{array}$ & $\begin{array}{l}\text { Noncommercialised } \\
\text { supplement }\end{array}$ & $\begin{array}{l}\mathrm{N}=40 \text { patients (eyes) } \\
\mathrm{S}=20 \\
\mathrm{C}=20 \\
\text { Mean age } \\
\mathrm{S} 63.6 \pm 3.1 \\
\mathrm{C} 62.2 \pm 3.4\end{array}$ & 14 & $\begin{array}{l}\text { VA: NS differences } \\
\text { CMT: NS differences } \\
\text { between groups. } \\
\text { Five eyes of the S } \\
\text { group showed } \\
\text { resolution of retinal } \\
\text { cysts, in comparison } \\
\text { to no changes in the } \\
\text { C group } \\
\text { RS (dB): S showed a } \\
\text { significant increase } \\
\text { at month } 14 \\
(p<0.001) \\
(16.43 \pm 0.39)\end{array}$ & $\begin{array}{l}\text { NS differences } \\
\text { during follow-up in } \\
\text { terms of HbA1c, } \\
\text { microalbuminuria or } \\
\text { blood pressure }\end{array}$ \\
\hline $\begin{array}{l}\text { Bursell } \\
\text { 1999 } \\
\text { USA } \\
\text { [157] }\end{array}$ & $\begin{array}{l}\text { Randomised } \\
\text { double-masked } \\
\text { placebo-controlled } \\
\text { crossover trial }\end{array}$ & $\begin{array}{l}\text { T1DM without or } \\
\text { with minimal DR }\end{array}$ & $\begin{array}{l}\mathrm{S}=\text { Vitamin E } 1800 \mathrm{IU} \\
\mathrm{C}=\text { Placebo capsule } \\
\text { Dosage } \\
1800 \mathrm{IU} / \text { day }\end{array}$ & $\begin{array}{l}\text { Noncommercialised } \\
\text { supplement }\end{array}$ & $\begin{array}{l}\mathrm{N}=45 \text { patients } \\
\mathrm{S}=36 \text { (T1DM) } \\
\mathrm{C}=9 \text { (ND) } \\
4 \text { months follow-up } \\
\text { Crossover } \\
\mathrm{S}=9 \text { (ND) } \\
\mathrm{C}=36 \text { (T1DM) } \\
4 \text { months follow-up } \\
\mathrm{Mean} \text { age } \\
\mathrm{DM}=31.2 \pm 6.8 \\
\mathrm{ND}=31.6 \pm 7.1\end{array}$ & 8 & $\begin{array}{l}\text { T1DM significant } \\
\text { increase in retinal } \\
\text { blood flow }(p<0.001) \\
(34.5 \pm 7.8 \\
\left.\text { pixel }^{2} / \mathrm{s}\right) \\
\text { Retinal blood flow } \\
\text { measured by mean } \\
\text { circulation times in } \\
\text { fluorescein } \\
\text { angiography: } \\
\text { C: No changes }\end{array}$ & $\begin{array}{l}\text { NS differences in } \\
\text { terms of HbA1c } \\
\text { between groups } \\
\text { Statistically } \\
\text { significant creatinine } \\
\text { clearance } \\
\text { improvement after } \\
\text { supplementation in } \\
\text { T1DM subjects } \\
(p=0.039) \text {. This } \\
\text { change reverted after } \\
\text { crossover. }\end{array}$ \\
\hline
\end{tabular}

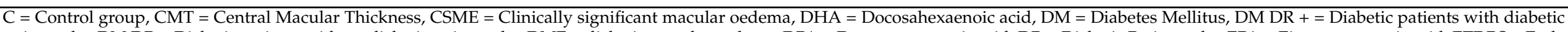

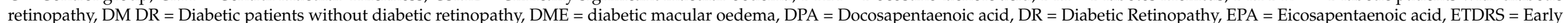

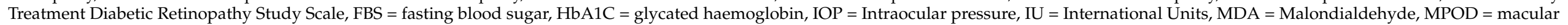

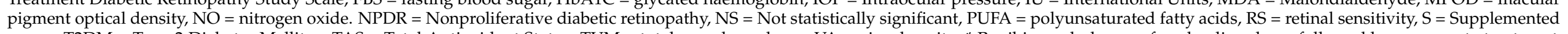

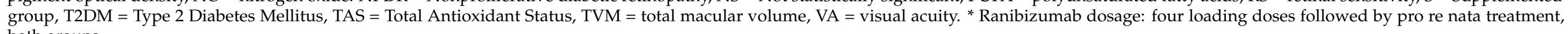
both groups. 


\subsubsection{Functional Variables Results}

Quite a different scene is observed regarding the influence of antioxidants on retinal function. Three studies included the analysis of retinal sensitivity [144,156], contrast sensitivity [144,148], glare sensitivity [144] and/or MPOD [144], and all of them observed a significant improvement in patients supplemented with Lutein, DiVFuSS ${ }^{\circledR}$ complex or C. Asiatica capsules. These changes were observed after relatively short follow-up periods, varying from six to fourteen months. The profile of the patients included by Zhang et al. and Chouss et al. was mild-to-moderate NPDR without CSME [144,148], while Forte et al. recruited T2DM patients with DME but without macular thickening in the OCT [156].

\subsubsection{Biochemical Variables Results}

Only three of the ten studies analysing $\mathrm{HbA} 1 \mathrm{c} \%$ values reported an improvement [129, $147,153]$ in supplemented patients. Concurrently, none of the studies could demonstrate significant changes in HDL/LDL/total cholesterol or triglyceride levels, nor were statistically significant results regarding microalbuminuria observed by Forte et al. [156]. Only Bursell et al. encountered an improvement in creatinine clearance in T1DM patients undergoing Vitamin E supplementation, but this effect was not maintained after a crossover period to placebo [157].

By contrast, promising numbers were observed regarding oxidation parameters. Among all the studies analysing antioxidant status [129,149-151,155], the changes reflected a significant reduction in lipid peroxidation end products and increased plasma total antioxidant capacity, in relation to Brudyretina ${ }^{\circledR}$, Nutrof Omega ${ }^{\circledR}$, Ubiquinone and Vitalux Forte ${ }^{\circledR}$ supplementation, both in studies with the shortest follow-up periods (six months) and the longest (60 months). Domanico et al. [152] were also able to demonstrate decreased ROS levels in patients supplemented with Diaberet ${ }^{\circledR}$.

As another interesting finding, Lafuente 2019 et al. [129] demonstrated a significant decrease in IL-6 plasma levels after 36 months of follow-up, suggesting an anti-inflammatory effect related to supplementation with DHA $\left(\right.$ Brudyretina $\left.^{\circledR}\right)$.

\subsubsection{Safety Profile}

The majority of the studies reported no adverse events related to oral supplementation. Bursell et al. detected low thyroid hormone levels in relation to Vitamin E in one patient; such levels recovered after the discontinuation of the antioxidant [157]. Haritoglou et al. reported nutritional, vascular, cardiac and nervous system disorders, as well as infections, in $46 \%$ of the supplemented individuals vs. $48 \%$ in the placebo group [154]. From them, 10 vs. 4 patients reporting treatment-emergent adverse events were attributed to the trial treatment (whether $\alpha$-lipoic acid or a placebo capsule), but its clinical nature was not specified and no mention about forced drug discontinuation is provided. In the study performed by Moon et al., $27 \%$ of the GSPE-supplemented subjects vs. $27.66 \%$ of the placebo group reported adverse reactions, which consisted of infections, gastrointestinal events, ocular and central nervous system disorders [146]. Gastrointestinal events were potentially associated with the treatment that was administered, and drugs were withdrawn in four patients of the supplemented group vs. one in the placebo group. Sanz-González et al. reported mild gastrointestinal discomfort related to Nutrof Omega ${ }^{\circledR}$ treatment, but no rates are specified and supplementation was not withdrawn [145].

Studies analysing T1DM patients had a mean follow-up time ranging from six to eight months and no children were included. Before recommending nutraceuticals to children with T1DM, more research is needed on their potential adverse effects over both the short and long term [158].

\subsubsection{Limitations}

Limitations of this systematic review include the high heterogeneity among studies, regarding the use of multiple antioxidants, the clinical variables studied and the follow-up 
periods, ranging from six to sixty months. Shorter follow-ups could explain the lack of significant results concerning clinical findings, given the chronic character of the disease.

Another considerable limitation would be the fact that some of the studies fail to assess administered drug levels and oxidation parameters [144,146-148,154,156,157], and they do not verify the treatment compliance or the further impact in oxidative status. Furthermore, the distribution of unknown amounts of antioxidants in the usual diet intake could influence the results. As an example, the group of Roig-Revert et al. did check the initial adherence of all the participants to the Mediterranean diet and took this factor into account for statistical analysis [151].

Data concerning drug bioavailability were only reported by two research groups. Lafuente et al. analysed the erythrocyte content of DHA and obtained significant differences among supplemented and placebo groups [129,149]. Sanz-González et al. measured vitamin $C$ levels and encountered inappropriate bioavailabilities, depending on different genetic expressions of SLC23A2 (which regulates intracellular levels of the vitamin), in the context of chronic hyperglycaemia and DR [145]. In addition, Haritoglou et al., who reported nonsignificant clinical results and did not measure supplemented $\alpha$-lipoic acid levels, postulated that administered doses might have not been enough to produce retinal changes, because the ideal dose in humans has not yet been established in comparison to well-defined safety levels in animal assays [154].

In this context, bioavailability, the fraction of bioactive compound that reaches the blood circulation, is usually very low in nutraceuticals. In recent years, nanoformulations have been used in order to increase the bioavailability of phenolic compounds, vitamins and minerals [159]. Likewise, other nutraceuticals with more bioavailability have appeared, such as pterostilbene, a resveratrol analogue whose bioavailability in rats is $80 \%$ compared to $20 \%$ for resveratrol [160].

\subsection{Conclusions}

According to the results gleaned from the studies, it can be deduced that clinical changes were only observed after the longest follow-up periods, in terms of delaying the onset or reducing the progression of DR in T2DM. No other clinical effects could be observed, which means that antioxidant supplementation has not yet been proven to have an impact on BCVA or DME regression in the mid-term.

On the other hand, antioxidants did show an early influence on retinal function parameters after short follow-up periods, ranging from six to fourteen months. The profile of these patients was T1 or T2DM subjects presenting mild-to-moderate NPDR without CSME, or with DME but without the thickening of the retina in the OCT. These findings suggest that antioxidants are a valid prophylactic adjuvant therapy in the early stages of DR, in which anatomical damage is not excessive and there is no thickening of the central macula.

Taking into account the heterogeneity of the variables studied and the large diversity of antioxidants administered in the RCTs, we would recommend antioxidant oral supplementation with a Ilb level of evidence in adult T1DM and T2DM patients without retinopathy or mild-to-moderate NPDR without DME.

In order to establish protocolled recommendations, larger sample sizes and longer follow-up periods should be accomplished in future clinical trials to determine the best antioxidant and the profile of candidates who will benefit from the adjuvant oral therapy in the mid- and long-term.

\section{The Future}

Despite the fact that the prevalence of diabetes is increasing worldwide, the advances in retinal imaging and new treatments have succeeded in reducing the rates of PDR and severe vision loss in developed countries.

The greater use of ultrawide-field photography of the fundus, which allows the evaluation of more than $80 \%$ of the retinal surface from a single image [161,162], and the 
improvement of noninvasive techniques, such as OCT angiography, for the early detection of microvascular damage in DR $[53,163,164]$ will encourage better management of these patients, giving telemedicine a fundamental role in the next few years.

These advances, together with AI algorithms, to detect DR may predict the risk of retinopathy progression more efficiently and in early stages $[165,166]$.

However, more than new diagnosis strategies, improved therapeutic approaches are still needed and are currently under investigation for the treatment of DR. These include emerging therapies for retinopathy that target alternative pathways for increased therapeutic effectiveness; alternative noninvasive delivery mechanisms or mechanisms providing a longer duration of action; approaches to prevent the onset of DR or to slow down the worsening of DR, such as oral antioxidant supplementation. In this review, we have staged the profile of patients who would benefit from antioxidant supplementation, adult T1DM and T2DM patients without retinopathy or mild-to-moderate NPDR without DME. However, new antioxidants with a higher bioavailability and better studies are needed to improve the level of evidence of this recommendation.

Finally, preclinical research suggests that gene therapy could be a promising therapeutic strategy for the future, eliminating the need for the frequent administration of anti-VEGF and increasing its brief therapeutic effect, which currently hinders the clinical practice [167].

Supplementary Materials: The following are available online at https:/ / www.mdpi.com/article/10 $.3390 /$ ijms22084020/s1, File S1: Inclusion and exclusion criteria, searches and excluded studies in the systematic review of clinical studies evaluating the effect of antioxidant supplementation in diabetic retinopathy (DR).

Author Contributions: All authors, E.A.A.-M., R.B.-S.d.l.M., J.M.B., J.C.M.M., and C.D., have contributed to writing and preparing the original draft; E.A.A.-M., R.B.-S.d.I.M. and C.D. have also contributed to writing, reviewing and editing this article; supervision was carried out by C.D. All authors have read and agreed to the published version of the manuscript.

Funding: This research received no external funding.

Institutional Review Board Statement: Not applicable.

Informed Consent Statement: Not applicable.

Acknowledgments: We thank Marilyn R. Noyes for reviewing the use of English in this manuscript.

Conflicts of Interest: The authors declare no conflict of interest.

\section{References}

1. Yau, J.W.; Rogers, S.L.; Kawasaki, R.; Lamoureux, E.L.; Kowalski, J.W.; Bek, T.; Chen, S.J.; Dekker, J.M.; Fletcher, A.; Grauslund, J.; et al. Global prevalence and major risk factors of diabetic retinopathy. Diabetes Care 2012, 35, 556-564. [CrossRef]

2. Williams, R.; Colagiuri, S.; Chan, J.; Gregg, E.W.; Ke, C.; Lim, L.-L.; Yang, X. IDF Diabetes Atlas 2019; International Diabetes Foundation. 2019. Available online: https://www.diabetesatlas.org/upload/resources/material/20200302_133351_IDFATLAS9 e-final-web.pdf (accessed on 13 March 2021).

3. Wong, T.Y.; Sun, J.; Kawasaki, R.; Ruamviboonsuk, P.; Gupta, N.; Lansingh, V.C.; Maia, M.; Mathenge, W.; Moreker, S.; Muqit, M.M.K.; et al. Guidelines on Diabetic Eye Care: The International Council of Ophthalmology Recommendations for Screening, Follow-up, Referral, and Treatment Based on Resource Settings. Ophthalmology 2018, 125, 1608-1622. [CrossRef]

4. Beagley, J;; Guariguata, L.; Weil, C.; Motala, A.A. Global estimates of undiagnosed diabetes in adults. Diabetes Res. Clin. Pract. 2014, 103, 150-160. [CrossRef]

5. Brownlee, M. The pathobiology of diabetic complications: A unifying mechanism. Diabetes 2005, 54, 1615-1625. [CrossRef] [PubMed]

6. Kowluru, R.A.; Chan, P.S. Oxidative stress and diabetic retinopathy. Exp. Diabetes Res. 2007, 2007, 43603. [CrossRef] [PubMed]

7. Garcia-Medina, J.J;; Rubio-Velazquez, E.; Foulquie-Moreno, E.; Casaroli-Marano, R.P.; Pinazo-Duran, M.D.; Zanon-Moreno, V.; Del-Rio-Vellosillo, M. Update on the Effects of Antioxidants on Diabetic Retinopathy: In Vitro Experiments, Animal Studies and Clinical Trials. Antioxidants 2020, 9, 561. [CrossRef] [PubMed]

8. Flaxman, S.R.; Bourne, R.R.A.; Resnikoff, S.; Ackland, P.; Braithwaite, T.; Cicinelli, M.V.; Das, A.; Jonas, J.B.; Keeffe, J.; Kempen, J.H.; et al. Global causes of blindness and distance vision impairment 1990-2020: A systematic review and metaanalysis. Lancet Glob. Health 2017, 5, e1221-e1234. [CrossRef] 
9. Bourne, R.R.; Stevens, G.A.; White, R.A.; Smith, J.L.; Flaxman, S.R.; Price, H.; Jonas, J.B.; Keeffe, J.; Leasher, J.; Naidoo, K.; et al. Causes of vision loss worldwide, 1990-2010: A systematic analysis. Lancet Glob. Health 2013, 1, e339-e349. [CrossRef]

10. Rodriguez, M.L.; Perez, S.; Mena-Molla, S.; Desco, M.C.; Ortega, A.L. Oxidative Stress and Microvascular Alterations in Diabetic Retinopathy: Future Therapies. Oxid. Med. Cell Longev. 2019, 2019, 4940825. [CrossRef]

11. Romero-Aroca, P.; Navarro-Gil, R.; Valls-Mateu, A.; Sagarra-Alamo, R.; Moreno-Ribas, A.; Soler, N. Differences in incidence of diabetic retinopathy between type 1 and 2 diabetes mellitus: A nine-year follow-up study. Br. J. Ophthalmol. 2017, 101, 1346-1351. [CrossRef]

12. Wong, M.Y.Z.; Man, R.E.K.; Fenwick, E.K.; Gupta, P.; Li, L.J.; van Dam, R.M.; Chong, M.F.; Lamoureux, E.L. Dietary intake and diabetic retinopathy: A systematic review. PLOS ONE 2018, 13, e0186582. [CrossRef] [PubMed]

13. Diabetes Control and Complications Trial (DCCT)/Epidemiology of Diabetes Interventions and Complications (EDIC) Study Research Group. Intensive Diabetes Treatment and Cardiovascular Outcomes in Type 1 Diabetes: The DCCT/EDIC Study 30-Year Follow-up. Diabetes Care 2016, 39, 686-693. [CrossRef] [PubMed]

14. UK Prospective Diabetes Study (UKPDS) Group. Effect of intensive blood-glucose control with metformin on complications in overweight patients with type 2 diabetes (UKPDS 34). Lancet 1998, 352, 854-865. [CrossRef]

15. Wu, M.Y.; Yiang, G.T.; Lai, T.T.; Li, C.J. The Oxidative Stress and Mitochondrial Dysfunction during the Pathogenesis of Diabetic Retinopathy. Oxid. Med. Cell Longev. 2018, 2018, 3420187. [CrossRef]

16. Xie, L.; Zhu, X.; Hu, Y.; Li, T.; Gao, Y.; Shi, Y.; Tang, S. Mitochondrial DNA oxidative damage triggering mitochondrial dysfunction and apoptosis in high glucose-induced HRECs. Investig. Ophthalmol. Vis. Sci. 2008, 49, 4203-4209. [CrossRef]

17. Madsen-Bouterse, S.A.; Mohammad, G.; Kanwar, M.; Kowluru, R.A. Role of mitochondrial DNA damage in the development of diabetic retinopathy, and the metabolic memory phenomenon associated with its progression. Antioxid. Redox. Signal. 2010, 13, 797-805. [CrossRef]

18. Wang, Z.; Zhao, H.; Guan, W.; Kang, X.; Tai, X.; Shen, Y. Metabolic memory in mitochondrial oxidative damage triggers diabetic retinopathy. BMC Ophthalmol. 2018, 18, 258. [CrossRef]

19. Pinto, C.C.; Silva, K.C.; Biswas, S.K.; Martins, N.; De Faria, J.B.; De Faria, J.M. Arterial hypertension exacerbates oxidative stress in early diabetic retinopathy. Free Radic. Res. 2007, 41, 1151-1158. [CrossRef]

20. Wang, W.; Lo, A.C.Y. Diabetic Retinopathy: Pathophysiology and Treatments. Int. J. Mol. Sci. 2018, 19, 1816. [CrossRef]

21. Altmann, C.; Schmidt, M.H.H. The Role of Microglia in Diabetic Retinopathy: Inflammation, Microvasculature Defects and Neurodegeneration. Int. J. Mol. Sci. 2018, 19, 110. [CrossRef]

22. Vujosevic, S.; Micera, A.; Bini, S.; Berton, M.; Esposito, G.; Midena, E. Aqueous Humor Biomarkers of Muller Cell Activation in Diabetic Eyes. Investig. Ophthalmol. Vis. Sci. 2015, 56, 3913-3918. [CrossRef]

23. Simo-Servat, O.; Hernandez, C.; Simo, R. Usefulness of the vitreous fluid analysis in the translational research of diabetic retinopathy. Mediat. Inflamm. 2012, 2012, 872978. [CrossRef]

24. Murugeswari, P.; Shukla, D.; Rajendran, A.; Kim, R.; Namperumalsamy, P.; Muthukkaruppan, V. Proinflammatory cytokines and angiogenic and anti-angiogenic factors in vitreous of patients with proliferative diabetic retinopathy and eales' disease. Retina 2008, 28, 817-824. [CrossRef]

25. Koleva-Georgieva, D.N.; Sivkova, N.P.; Terzieva, D. Serum inflammatory cytokines IL-1beta, IL-6, TNF-alpha and VEGF have influence on the development of diabetic retinopathy. Folia Med. 2011, 53, 44-50. [CrossRef]

26. Rubsam, A.; Parikh, S.; Fort, P.E. Role of Inflammation in Diabetic Retinopathy. Int. J. Mol. Sci. 2018, 19, 942. [CrossRef]

27. Miyamoto, K.; Khosrof, S.; Bursell, S.E.; Rohan, R.; Murata, T.; Clermont, A.C.; Aiello, L.P.; Ogura, Y.; Adamis, A.P. Prevention of leukostasis and vascular leakage in streptozotocin-induced diabetic retinopathy via intercellular adhesion molecule-1 inhibition. Proc. Natl. Acad. Sci. USA 1999, 96, 10836-10841. [CrossRef] [PubMed]

28. Blum, A.; Pastukh, N.; Socea, D.; Jabaly, H. Levels of adhesion molecules in peripheral blood correlat with stages of diabetic retinopathy and may serve as bio markers for microvascular complications. Cytokine 2018, 106, 76-79. [CrossRef] [PubMed]

29. Tian, P.; Ge, H.; Liu, H.; Kern, T.S.; Du, L.; Guan, L.; Su, S.; Liu, P. Leukocytes from diabetic patients kill retinal endothelial cells: Effects of berberine. Mol. Vis. 2013, 19, 2092-2105. [PubMed]

30. Tyrberg, M.; Lindblad, U.; Melander, A.; Lovestam-Adrian, M.; Ponjavic, V.; Andreasson, S. Electrophysiological studies in newly onset type 2 diabetes without visible vascular retinopathy. Doc. Ophthalmol. 2011, 123, 193-198. [CrossRef] [PubMed]

31. Sasaki, M.; Ozawa, Y.; Kurihara, T.; Kubota, S.; Yuki, K.; Noda, K.; Kobayashi, S.; Ishida, S.; Tsubota, K. Neurodegenerative influence of oxidative stress in the retina of a murine model of diabetes. Diabetologia 2010, 53, 971-979. [CrossRef] [PubMed]

32. Sohn, E.H.; van Dijk, H.W.; Jiao, C.; Kok, P.H.; Jeong, W.; Demirkaya, N.; Garmager, A.; Wit, F.; Kucukevcilioglu, M.; van Velthoven, M.E.; et al. Retinal neurodegeneration may precede microvascular changes characteristic of diabetic retinopathy in diabetes mellitus. Proc. Natl. Acad. Sci. USA 2016, 113, E2655-E2664. [CrossRef]

33. Romeo, G.; Liu, W.H.; Asnaghi, V.; Kern, T.S.; Lorenzi, M. Activation of nuclear factor-kappaB induced by diabetes and high glucose regulates a proapoptotic program in retinal pericytes. Diabetes 2002, 51, 2241-2248. [CrossRef] [PubMed]

34. Durham, J.T.; Herman, I.M. Microvascular modifications in diabetic retinopathy. Curr. Diab. Rep. 2011, 11, 253-264. [CrossRef]

35. Zhang, D.; Lv, F.L.; Wang, G.H. Effects of HIF-1alpha on diabetic retinopathy angiogenesis and VEGF expression. Eur. Rev. Med. Pharmacol. Sci. 2018, 22, 5071-5076. [CrossRef] [PubMed] 
36. Wilkinson, C.P.; Ferris, F.L., 3rd; Klein, R.E.; Lee, P.P.; Agardh, C.D.; Davis, M.; Dills, D.; Kampik, A.; Pararajasegaram, R.; Verdaguer, J.T.; et al. Proposed international clinical diabetic retinopathy and diabetic macular edema disease severity scales. Ophthalmology 2003, 110, 1677-1682. [CrossRef]

37. Lee, C.S.; Lee, A.Y.; Baughman, D.; Sim, D.; Akelere, T.; Brand, C.; Crabb, D.P.; Denniston, A.K.; Downey, L.; Fitt, A.; et al. The United Kingdom Diabetic Retinopathy Electronic Medical Record Users Group: Report 3: Baseline Retinopathy and Clinical Features Predict Progression of Diabetic Retinopathy. Am. J. Ophthalmol. 2017, 180, 64-71. [CrossRef] [PubMed]

38. Pereira, D.M.; Shah, A.; D'Souza, M.; Simon, P.; George, T.; D'Souza, N.; Suresh, S.; Baliga, M.S. Quality of Life in People with Diabetic Retinopathy: Indian Study. J. Clin. Diagn. Res. 2017, 11, NC01-NC06. [CrossRef]

39. Fenwick, E.K.; Man, R.E.K.; Gan, A.T.L.; Kumari, N.; Wong, C.; Aravindhan, A.; Gupta, P.; Wang, J.J.; Mitchell, P.; Wong, T.Y.; et al. Beyond vision loss: The independent impact of diabetic retinopathy on vision-related quality of life in a Chinese Singaporean population. Br. J. Ophthalmol. 2019, 103, 1314-1319. [CrossRef]

40. Ihnat, M.A.; Thorpe, J.E.; Kamat, C.D.; Szabo, C.; Green, D.E.; Warnke, L.A.; Lacza, Z.; Cselenyak, A.; Ross, K.; Shakir, S.; et al. Reactive oxygen species mediate a cellular 'memory' of high glucose stress signalling. Diabetologia 2007, 50, 1523-1531. [CrossRef]

41. Kowluru, R.A.; Mohammad, G. Epigenetics and Mitochondrial Stability in the Metabolic Memory Phenomenon Associated with Continued Progression of Diabetic Retinopathy. Sci. Rep. 2020, 10, 6655. [CrossRef]

42. Bernardes, R.; Serranho, P.; Lobo, C. Digital ocular fundus imaging: A review. Ophthalmologica 2011, 226, 161-181. [CrossRef] [PubMed]

43. Shi, L.; Wu, H.; Dong, J.; Jiang, K.; Lu, X.; Shi, J. Telemedicine for detecting diabetic retinopathy: A systematic review and meta-analysis. Br. J. Ophthalmol. 2015, 99, 823-831. [CrossRef] [PubMed]

44. Fenner, B.J.; Wong, R.L.M.; Lam, W.C.; Tan, G.S.W.; Cheung, G.C.M. Advances in Retinal Imaging and Applications in Diabetic Retinopathy Screening: A Review. Ophthalmol. Ther. 2018, 7, 333-346. [CrossRef]

45. Silva, P.S.; Dela Cruz, A.J.; Ledesma, M.G.; van Hemert, J.; Radwan, A.; Cavallerano, J.D.; Aiello, L.M.; Sun, J.K.; Aiello, L.P. Diabetic Retinopathy Severity and Peripheral Lesions Are Associated with Nonperfusion on Ultrawide Field Angiography. Ophthalmology 2015, 122, 2465-2472. [CrossRef] [PubMed]

46. Zimmer-Galler, I.E.; Zeimer, R. Telemedicine in diabetic retinopathy screening. Int. Ophthalmol. Clin. 2009, 49, 75-86. [CrossRef]

47. Scanlon, P.H. The English National Screening Programme for diabetic retinopathy 2003-2016. Acta Diabetol. 2017, 54, 515-525. [CrossRef]

48. Wong, R.L.; Tsang, C.W.; Wong, D.S.; McGhee, S.; Lam, C.H.; Lian, J.; Lee, J.W.; Lai, J.S.; Chong, V.; Wong, I.Y. Are we making good use of our public resources? The false-positive rate of screening by fundus photography for diabetic macular oedema. Hong Kong Med. J. 2017, 23, 356-364. [CrossRef]

49. Prescott, G.; Sharp, P.; Goatman, K.; Scotland, G.; Fleming, A.; Philip, S.; Staff, R.; Santiago, C.; Borooah, S.; Broadbent, D.; et al. Improving the cost-effectiveness of photographic screening for diabetic macular oedema: A prospective, multi-centre, UK study. Br. J. Ophthalmol. 2014, 98, 1042-1049. [CrossRef] [PubMed]

50. Sun, J.K.; Radwan, S.H.; Soliman, A.Z.; Lammer, J.; Lin, M.M.; Prager, S.G.; Silva, P.S.; Aiello, L.B.; Aiello, L.P. Neural Retinal Disorganization as a Robust Marker of Visual Acuity in Current and Resolved Diabetic Macular Edema. Diabetes 2015, 64, 2560-2570. [CrossRef] [PubMed]

51. Tan, A.C.S.; Tan, G.S.; Denniston, A.K.; Keane, P.A.; Ang, M.; Milea, D.; Chakravarthy, U.; Cheung, C.M.G. An overview of the clinical applications of optical coherence tomography angiography. Eye 2018, 32, 262-286. [CrossRef]

52. Ting, D.S.W.; Tan, G.S.W.; Agrawal, R.; Yanagi, Y.; Sie, N.M.; Wong, C.W.; San Yeo, I.Y.; Lee, S.Y.; Cheung, C.M.G.; Wong, T.Y. Optical Coherence Tomographic Angiography in Type 2 Diabetes and Diabetic Retinopathy. JAMA Ophthalmol. 2017, 135, 306-312. [CrossRef] [PubMed]

53. Samara, W.A.; Shahlaee, A.; Adam, M.K.; Khan, M.A.; Chiang, A.; Maguire, J.I.; Hsu, J.; Ho, A.C. Quantification of Diabetic Macular Ischemia Using Optical Coherence Tomography Angiography and Its Relationship with Visual Acuity. Ophthalmology 2017, 124, 235-244. [CrossRef]

54. Wadhwani, M.; Vashist, P.; Singh, S.S.; Gupta, N.; Malhotra, S.; Gupta, A.; Shukla, P.; Bhardwaj, A.; Gupta, V. Diabetic retinopathy screening programme utilising non-mydriatic fundus imaging in slum populations of New Delhi, India. Trop. Med. Int. Health 2018, 23, 405-414. [CrossRef] [PubMed]

55. Gardner, G.G.; Keating, D.; Williamson, T.H.; Elliott, A.T. Automatic detection of diabetic retinopathy using an artificial neural network: A screening tool. Br. J. Ophthalmol. 1996, 80, 940-944. [CrossRef] [PubMed]

56. Ting, D.S.W.; Cheung, C.Y.; Lim, G.; Tan, G.S.W.; Quang, N.D.; Gan, A.; Hamzah, H.; Garcia-Franco, R.; San Yeo, I.Y.; Lee, S.Y.; et al. Development and Validation of a Deep Learning System for Diabetic Retinopathy and Related Eye Diseases Using Retinal Images From Multiethnic Populations With Diabetes. JAMA 2017, 318, 2211-2223. [CrossRef]

57. Gargeya, R.; Leng, T. Automated Identification of Diabetic Retinopathy Using Deep Learning. Ophthalmology 2017, 124, 962-969. [CrossRef] [PubMed]

58. Krause, J.; Gulshan, V.; Rahimy, E.; Karth, P.; Widner, K.; Corrado, G.S.; Peng, L.; Webster, D.R. Grader Variability and the Importance of Reference Standards for Evaluating Machine Learning Models for Diabetic Retinopathy. Ophthalmology 2018, 125, 1264-1272. [CrossRef] 
59. Van der Heijden, A.A.; Abramoff, M.D.; Verbraak, F.; van Hecke, M.V.; Liem, A.; Nijpels, G. Validation of automated screening for referable diabetic retinopathy with the IDx-DR device in the Hoorn Diabetes Care System. Acta Ophthalmol. 2018, 96, 63-68. [CrossRef]

60. Amoaku, W.M.; Ghanchi, F.; Bailey, C.; Banerjee, S.; Banerjee, S.; Downey, L.; Gale, R.; Hamilton, R.; Khunti, K.; Posner, E.; et al. Diabetic retinopathy and diabetic macular oedema pathways and management: UK Consensus Working Group. Eye 2020, 34, 1-51. [CrossRef]

61. Scanlon, P.H.; Stratton, I.M.; Bachmann, M.O.; Jones, C.; Leese, G.P.; Four Nations Diabetic Retinopathy Screening Study Group. Risk of diabetic retinopathy at first screen in children at 12 and 13 years of age. Diabet. Med. 2016, 33, 1655-1658. [CrossRef]

62. Flaxel, C.J.; Adelman, R.A.; Bailey, S.T.; Fawzi, A.; Lim, J.I.; Vemulakonda, G.A.; Ying, G.-s. Diabetic Retinopathy Preferred Practice Pattern ${ }^{\circledR}$. Ophthalmology 2020, 127, P66-P145. [CrossRef]

63. Fan, W.; Nittala, M.G.; Velaga, S.B.; Hirano, T.; Wykoff, C.C.; Ip, M.; Lampen, S.I.R.; van Hemert, J.; Fleming, A.; Verhoek, M.; et al. Distribution of Nonperfusion and Neovascularization on Ultrawide-Field Fluorescein Angiography in Proliferative Diabetic Retinopathy (RECOVERY Study): Report 1. Am. J. Ophthalmol. 2019, 206, 154-160. [CrossRef]

64. Ashraf, M.; Sampani, K.; AbdelAl, O.; Fleming, A.; Cavallerano, J.; Souka, A.; El Baha, S.M.; Silva, P.S.; Sun, J.; Aiello, L.P. Disparity of microaneurysm count between ultrawide field colour imaging and ultrawide field fluorescein angiography in eyes with diabetic retinopathy. Br. J. Ophthalmol. 2020. [CrossRef]

65. Rayess, N.; Rahimy, E.; Ying, G.S.; Bagheri, N.; Ho, A.C.; Regillo, C.D.; Vander, J.F.; Hsu, J. Baseline choroidal thickness as a predictor for response to anti-vascular endothelial growth factor therapy in diabetic macular edema. Am. J. Ophthalmol. 2015, 159, 85-91.e3. [CrossRef] [PubMed]

66. Wang, J.; Hormel, T.T.; You, Q.; Guo, Y.; Wang, X.; Chen, L.; Hwang, T.S.; Jia, Y. Robust non-perfusion area detection in three retinal plexuses using convolutional neural network in OCT angiography. Biomed. Opt. Express 2020, 11, 330-345. [CrossRef] [PubMed]

67. Wang, F.; Saraf, S.S.; Zhang, Q.; Wang, R.K.; Rezaei, K.A. Ultra-Widefield Protocol Enhances Automated Classification of Diabetic Retinopathy Severity with OCT Angiography. Ophthalmol. Retina 2020, 4, 415-424. [CrossRef]

68. Liu, G.; Xu, D.; Wang, F. New insights into diabetic retinopathy by OCT angiography. Diabetes Res. Clin. Pract. 2018, 142, 243-253 [CrossRef] [PubMed]

69. Virk, R.; Binns, A.M.; Chambers, R.; Anderson, J. How is the risk of being diagnosed with referable diabetic retinopathy affected by failure to attend diabetes eye screening appointments? Eye 2020. [CrossRef] [PubMed]

70. Frith, E.; Loprinzi, P.D. Retinopathy and Mortality. Diabetes Spectr. 2018, 31, 184-188. [CrossRef]

71. Ferris, F.L., 3rd. How effective are treatments for diabetic retinopathy? JAMA 1993, 269, 1290-1291. [CrossRef]

72. Testa, R.; Bonfigli, A.R.; Prattichizzo, F.; La Sala, L.; De Nigris, V.; Ceriello, A. The "Metabolic Memory" Theory and the Early Treatment of Hyperglycemia in Prevention of Diabetic Complications. Nutrients 2017, 9, 437. [CrossRef]

73. Diabetes Control and Complications Trial Research Group. The relationship of glycemic exposure (HbA1c) to the risk of development and progression of retinopathy in the diabetes control and complications trial. Diabetes 1995, 44, 968-983. [CrossRef]

74. Richardson, P.; Hulpus, A.; Idris, I. Short-Term Impact of Bariatric Surgery on Best-Corrected Distance Visual Acuity and Diabetic Retinopathy Progression. Obes. Surg. 2018, 28, 3711-3713. [CrossRef]

75. Imran, S.A.; Agarwal, G.; Bajaj, H.S.; Ross, S. Targets for Glycemic Control. Can. J. Diabetes 2018, 42 (Suppl. 1), S42-S46. [CrossRef] [PubMed]

76. UK Prospective Diabetes Study Group. Tight blood pressure control and risk of macrovascular and microvascular complications in type 2 diabetes: UKPDS 38. BMJ 1998, 317, 703-713. [CrossRef]

77. Do, D.V.; Wang, X.; Vedula, S.S.; Marrone, M.; Sleilati, G.; Hawkins, B.S.; Frank, R.N. Blood pressure control for diabetic retinopathy. Cochrane Database Syst. Rev. 2015, 1, CD006127. [CrossRef] [PubMed]

78. Zhou, J.B.; Song, Z.H.; Bai, L.; Zhu, X.R.; Li, H.B.; Yang, J.K. Could Intensive Blood Pressure Control Really Reduce Diabetic Retinopathy Outcomes? Evidence from Meta-Analysis and Trial Sequential Analysis from Randomized Controlled Trials. Diabetes Ther. 2018, 9, 2015-2027. [CrossRef]

79. Keech, A.C.; Mitchell, P.; Summanen, P.A.; O’Day, J.; Davis, T.M.; Moffitt, M.S.; Taskinen, M.R.; Simes, R.J.; Tse, D.; Williamson, E.; et al. Effect of fenofibrate on the need for laser treatment for diabetic retinopathy (FIELD study): A randomised controlled trial. Lancet 2007, 370, 1687-1697. [CrossRef]

80. Group, A.S.; Group, A.E.S.; Chew, E.Y.; Ambrosius, W.T.; Davis, M.D.; Danis, R.P.; Gangaputra, S.; Greven, C.M.; Hubbard, L.; Esser, B.A.; et al. Effects of medical therapies on retinopathy progression in type 2 diabetes. N. Engl. J. Med. 2010, 363, 233-244. [CrossRef]

81. Zhu, W.; Wu, Y.; Meng, Y.F.; Xing, Q.; Tao, J.J.; Lu, J. Association of obesity and risk of diabetic retinopathy in diabetes patients: A meta-analysis of prospective cohort studies. Medicine 2018, 97, e11807. [CrossRef]

82. Cai, X.; Chen, Y.; Yang, W.; Gao, X.; Han, X.; Ji, L. The association of smoking and risk of diabetic retinopathy in patients with type 1 and type 2 diabetes: A meta-analysis. Endocrine 2018, 62, 299-306. [CrossRef]

83. Aguirre, F.; Brown, A.; Cho, N.H.; Dahlquist, G.; Dodd, S.; Dunning, T.; Hirst, M.; Hwang, C.; Magliano, D.; Patterson, C.; et al. IDF Diabetes Atlas: Sixth Edition; International Diabetes Federation. 2013. Available online: http://dro.deakin.edu.au/view/DU: 30060687 (accessed on 13 March 2021). 
84. Rasmussen, K.L.; Laugesen, C.S.; Ringholm, L.; Vestgaard, M.; Damm, P.; Mathiesen, E.R. Progression of diabetic retinopathy during pregnancy in women with type 2 diabetes. Diabetologia 2010, 53, 1076-1083. [CrossRef] [PubMed]

85. Klein, B.E.; Moss, S.E.; Klein, R. Effect of pregnancy on progression of diabetic retinopathy. Diabetes Care 1990, 13, 34-40. [CrossRef] [PubMed]

86. Morrison, J.L.; Hodgson, L.A.; Lim, L.L.; Al-Qureshi, S. Diabetic retinopathy in pregnancy: A review. Clin. Exp. Ophthalmol. 2016, 44, 321-334. [CrossRef] [PubMed]

87. The Diabetes Control and Complications Trial Research Group. Effect of pregnancy on microvascular complications in the diabetes control and complications trial. Diabetes Care 2000, 23, 1084-1091. [CrossRef]

88. Helen, C.C.; Tajunisah, I.; Reddy, S.C. Adverse outcomes in Type I diabetic pregnant women with proliferative diabetic retinopathy. Int J. Ophthalmol. 2011, 4, 443-446. [CrossRef] [PubMed]

89. Chan, W.C.; Lim, L.T.; Quinn, M.J.; Knox, F.A.; McCance, D.; Best, R.M. Management and outcome of sight-threatening diabetic retinopathy in pregnancy. Eye 2004, 18, 826-832. [CrossRef]

90. Fazelat, A.; Lashkari, K. Off-label use of intravitreal triamcinolone acetonide for diabetic macular edema in a pregnant patient. Clin. Ophthalmol. 2011, 5, 439-441. [CrossRef]

91. Yoo, R.; Kim, H.C.; Chung, H. Dexamethasone intravitreal implant for diabetic macular edema in a pregnant patient. Int. J. Ophthalmol. 2016, 9, 1524-1527. [CrossRef]

92. Concillado, M.; Lund-Andersen, H.; Mathiesen, E.R.; Larsen, M. Dexamethasone Intravitreal Implant for Diabetic Macular Edema During Pregnancy. Am. J. Ophthalmol. 2016, 165, 7-15. [CrossRef]

93. Jamilian, M.; Mirhosseini, N.; Eslahi, M.; Bahmani, F.; Shokrpour, M.; Chamani, M.; Asemi, Z. The effects of magnesium-zinccalcium-vitamin D co-supplementation on biomarkers of inflammation, oxidative stress and pregnancy outcomes in gestational diabetes. BMC Pregnancy Childbirth 2019, 19, 107. [CrossRef]

94. Tham, Y.C.; Liu, L.; Rim, T.H.; Zhang, L.; Majithia, S.; Chee, M.L.; Tan, N.Y.Q.; Wong, K.H.; Ting, D.S.W.; Sabanayagam, C.; et al. Association of Cataract Surgery with Risk of Diabetic Retinopathy Among Asian Participants in the Singapore Epidemiology of Eye Diseases Study. JAMA Netw. Open 2020, 3, e208035. [CrossRef] [PubMed]

95. Denniston, A.K.; Chakravarthy, U.; Zhu, H.; Lee, A.Y.; Crabb, D.P.; Tufail, A.; Bailey, C.; Akerele, T.; Al-Husainy, S.; Brand, C.; et al. The UK Diabetic Retinopathy Electronic Medical Record (UK DR EMR) Users Group, Report 2: Real-world data for the impact of cataract surgery on diabetic macular oedema. Br. J. Ophthalmol. 2017, 101, 1673-1678. [CrossRef] [PubMed]

96. Hovland, P.G. Diabetic Retinopathy Severity and Cataract Surgery: When Less Is More. Ophthalmol. Retina 2020, 4, 349-350. [CrossRef] [PubMed]

97. Sasongko, M.B.; Rogers, S.; Constantinou, M.; Sandhu, S.S.; Wickremasinghe, S.S.; Al-Qureshi, S.; Lim, L.L. Diabetic retinopathy progression 6 months post-cataract surgery with intravitreous bevacizumab vs triamcinolone: A secondary analysis of the DiMECAT trial. Clin. Exp. Ophthalmol. 2020. [CrossRef] [PubMed]

98. Zhao, L.Q.; Cheng, J.W. A Systematic Review and Meta-Analysis of Clinical Outcomes of Intravitreal Anti-VEGF Agent Treatment Immediately after Cataract Surgery for Patients with Diabetic Retinopathy. J. Ophthalmol. 2019, 2019, 2648267. [CrossRef]

99. Feng, Y.; Zhu, S.; Skiadaresi, E.; McAlinden, C.; Tu, R.; Gao, R.; Stephens, J.W.; Wang, Q.; Huang, J. Phacoemulsification cataract surgery with prophylactic intravitreal bevacizumab for patients with coexisting diabetic retinopathy: A Meta-Analysis. Retina 2019, 39, 1720-1731. [CrossRef]

100. Diabetic Retinopathy Study Research Group. Preliminary report on effects of photocoagulation therapy. Am. J. Ophthalmol. 1976, 81, 383-396. [CrossRef]

101. Diabetic Retinopathy Study Research Group. Photocoagulation treatment of proliferative diabetic retinopathy: Relationship of adverse treatment effects to retinopathy severity. Diabetic retinopathy study report no. 5. Dev. Ophthalmol. 1981, 2, $248-261$.

102. Funatsu, H.; Yamashita, H.; Noma, H.; Mimura, T.; Yamashita, T.; Hori, S. Increased levels of vascular endothelial growth factor and interleukin-6 in the aqueous humor of diabetics with macular edema. Am. J. Ophthalmol. 2002, 133, 70-77. [CrossRef]

103. Aiello, L.P.; Avery, R.L.; Arrigg, P.G.; Keyt, B.A.; Jampel, H.D.; Shah, S.T.; Pasquale, L.R.; Thieme, H.; Iwamoto, M.A.; Park, J.E.; et al. Vascular endothelial growth factor in ocular fluid of patients with diabetic retinopathy and other retinal disorders. N. Engl. J. Med. 1994, 331, 1480-1487. [CrossRef]

104. Gross, J.G.; Glassman, A.R.; Jampol, L.M.; Inusah, S.; Aiello, L.P.; Antoszyk, A.N.; Baker, C.W.; Berger, B.B.; Bressler, N.M.; Browning, D.; et al. Panretinal Photocoagulation vs Intravitreous Ranibizumab for Proliferative Diabetic Retinopathy: A Randomized Clinical Trial. JAMA 2015, 314, 2137-2146. [CrossRef]

105. Sivaprasad, S.; Prevost, A.T.; Vasconcelos, J.C.; Riddell, A.; Murphy, C.; Kelly, J.; Bainbridge, J.; Tudor-Edwards, R.; Hopkins, D.; Hykin, P.; et al. Clinical efficacy of intravitreal aflibercept versus panretinal photocoagulation for best corrected visual acuity in patients with proliferative diabetic retinopathy at 52 weeks (CLARITY): A multicentre, single-blinded, randomised, controlled, phase 2b, non-inferiority trial. Lancet 2017, 389, 2193-2203. [CrossRef]

106. Beaulieu, W.T.; Bressler, N.M.; Melia, M.; Owsley, C.; Mein, C.E.; Gross, J.G.; Jampol, L.M.; Glassman, A.R.; Diabetic Retinopathy Clinical Research, N. Panretinal Photocoagulation Versus Ranibizumab for Proliferative Diabetic Retinopathy: Patient-Centered Outcomes from a Randomized Clinical Trial. Am. J. Ophthalmol. 2016, 170, 206-213. [CrossRef] [PubMed]

107. Figueira, J.; Fletcher, E.; Massin, P.; Silva, R.; Bandello, F.; Midena, E.; Varano, M.; Sivaprasad, S.; Eleftheriadis, H.; Menon, G.; et al Ranibizumab Plus Panretinal Photocoagulation versus Panretinal Photocoagulation Alone for High-Risk Proliferative Diabetic Retinopathy (PROTEUS Study). Ophthalmology 2018, 125, 691-700. [CrossRef] 
108. Glassman, A.R. Results of a Randomized Clinical Trial of Aflibercept vs Panretinal Photocoagulation for Proliferative Diabetic Retinopathy: Is It Time to Retire Your Laser? JAMA Ophthalmol. 2017, 135, 685-686. [CrossRef] [PubMed]

109. Gross, J.G.; Glassman, A.R.; Liu, D.; Sun, J.K.; Antoszyk, A.N.; Baker, C.W.; Bressler, N.M.; Elman, M.J.; Ferris, F.L., 3rd; Gardner, T.W.; et al. Five-Year Outcomes of Panretinal Photocoagulation vs Intravitreous Ranibizumab for Proliferative Diabetic Retinopathy: A Randomized Clinical Trial. JAMA Ophthalmol. 2018, 136, 1138-1148. [CrossRef]

110. Obeid, A.; Gao, X.; Ali, F.S.; Talcott, K.E.; Aderman, C.M.; Hyman, L.; Ho, A.C.; Hsu, J. Loss to Follow-Up in Patients with Proliferative Diabetic Retinopathy after Panretinal Photocoagulation or Intravitreal Anti-VEGF Injections. Ophthalmology 2018, 125, 1386-1392. [CrossRef]

111. Obeid, A.; Su, D.; Patel, S.N.; Uhr, J.H.; Borkar, D.; Gao, X.; Fineman, M.S.; Regillo, C.D.; Maguire, J.I.; Garg, S.J.; et al. Outcomes of Eyes Lost to Follow-up with Proliferative Diabetic Retinopathy That Received Panretinal Photocoagulation versus Intravitreal Anti-Vascular Endothelial Growth Factor. Ophthalmology 2019, 126, 407-413. [CrossRef]

112. Jampol, L.M.; Glassman, A.R.; Sun, J. Evaluation and Care of Patients with Diabetic Retinopathy. N. Engl. J. Med. 2020, 382, 1629-1637. [CrossRef]

113. Sun, J.K.; Glassman, A.R.; Beaulieu, W.T.; Stockdale, C.R.; Bressler, N.M.; Flaxel, C.; Gross, J.G.; Shami, M.; Jampol, L.M.; Diabetic Retinopathy Clinical Research Network. Rationale and Application of the Protocol S Anti-Vascular Endothelial Growth Factor Algorithm for Proliferative Diabetic Retinopathy. Ophthalmology 2019, 126, 87-95. [CrossRef]

114. Diabetic Retinopathy Study Research Group. Photocoagulation for diabetic macular edema. Early Treatment Diabetic Retinopathy Study report number 1. Arch. Ophthalmol. 1985, 103, 1796-1806. [CrossRef]

115. Relhan, N.; Flynn, H.W., Jr. The Early Treatment Diabetic Retinopathy Study historical review and relevance to today's management of diabetic macular edema. Curr. Opin. Ophthalmol. 2017, 28, 205-212. [CrossRef]

116. Diabetic Retinopathy Clinical Research Network. A randomized trial comparing intravitreal triamcinolone acetonide and focal/grid photocoagulation for diabetic macular edema. Ophthalmology 2008, 115, 1447-1459.e10. [CrossRef] [PubMed]

117. Diabetic Retinopathy Clinical Research Network; Elman, M.J.; Aiello, L.P.; Beck, R.W.; Bressler, N.M.; Bressler, S.B.; Edwards, A.R.; Ferris, F.L., 3rd; Friedman, S.M.; Glassman, A.R.; et al. Randomized trial evaluating ranibizumab plus prompt or deferred laser or triamcinolone plus prompt laser for diabetic macular edema. Ophthalmology 2010, 117, 1064-1077.e35. [CrossRef]

118. Michaelides, M.; Kaines, A.; Hamilton, R.D.; Fraser-Bell, S.; Rajendram, R.; Quhill, F.; Boos, C.J.; Xing, W.; Egan, C.; Peto, T.; et al. A prospective randomized trial of intravitreal bevacizumab or laser therapy in the management of diabetic macular edema (BOLT study) 12-month data: Report 2. Ophthalmology 2010, 117, 1078-1086.e2. [CrossRef] [PubMed]

119. Mitchell, P.; Bandello, F.; Schmidt-Erfurth, U.; Lang, G.E.; Massin, P.; Schlingemann, R.O.; Sutter, F.; Simader, C.; Burian, G.; Gerstner, O.; et al. The RESTORE study: Ranibizumab monotherapy or combined with laser versus laser monotherapy for diabetic macular edema. Ophthalmology 2011, 118, 615-625. [CrossRef] [PubMed]

120. Nguyen, Q.D.; Brown, D.M.; Marcus, D.M.; Boyer, D.S.; Patel, S.; Feiner, L.; Gibson, A.; Sy, J.; Rundle, A.C.; Hopkins, J.J.; et al. Ranibizumab for diabetic macular edema: Results from 2 phase III randomized trials: RISE and RIDE. Ophthalmology 2012, 119, 789-801. [CrossRef] [PubMed]

121. Brown, D.M.; Schmidt-Erfurth, U.; Do, D.V.; Holz, F.G.; Boyer, D.S.; Midena, E.; Heier, J.S.; Terasaki, H.; Kaiser, P.K.; Marcus, D.M.; et al. Intravitreal Aflibercept for Diabetic Macular Edema: 100-Week Results from the VISTA and VIVID Studies. Ophthalmology 2015, 122, 2044-2052. [CrossRef] [PubMed]

122. Elman, M.J.; Bressler, N.M.; Qin, H.; Beck, R.W.; Ferris, F.L., 3rd; Friedman, S.M.; Glassman, A.R.; Scott, I.U.; Stockdale, C.R.; Sun, J.K.; et al. Expanded 2-year follow-up of ranibizumab plus prompt or deferred laser or triamcinolone plus prompt laser for diabetic macular edema. Ophthalmology 2011, 118, 609-614. [CrossRef] [PubMed]

123. Bressler, N.M.; Beaulieu, W.T.; Glassman, A.R.; Blinder, K.J.; Bressler, S.B.; Jampol, L.M.; Melia, M.; Wells, J.A., 3rd; Diabetic Retinopathy Clinical Research, N. Persistent Macular Thickening Following Intravitreous Aflibercept, Bevacizumab, or Ranibizumab for Central-Involved Diabetic Macular Edema With Vision Impairment: A Secondary Analysis of a Randomized Clinical Trial. JAMA Ophthalmol. 2018, 136, 257-269. [CrossRef] [PubMed]

124. Glassman, A.R.; Wells, J.A., 3rd; Josic, K.; Maguire, M.G.; Antoszyk, A.N.; Baker, C.; Beaulieu, W.T.; Elman, M.J.; Jampol, L.M.; Sun, J.K. Five-Year Outcomes after Initial Aflibercept, Bevacizumab, or Ranibizumab Treatment for Diabetic Macular Edema (Protocol T Extension Study). Ophthalmology 2020. [CrossRef] [PubMed]

125. Maturi, R.K.; Pollack, A.; Uy, H.S.; Varano, M.; Gomes, A.M.; Li, X.Y.; Cui, H.; Lou, J.; Hashad, Y.; Whitcup, S.M.; et al. Intraocular Pressure in Patients with Diabetic Macular Edema Treated with Dexamethasone Intravitreal Implant in the 3-Year Mead Study. Retina 2016, 36, 1143-1152. [CrossRef] [PubMed]

126. Campochiaro, P.A.; Brown, D.M.; Pearson, A.; Chen, S.; Boyer, D.; Ruiz-Moreno, J.; Garretson, B.; Gupta, A.; Hariprasad, S.M.; Bailey, C.; et al. Sustained delivery fluocinolone acetonide vitreous inserts provide benefit for at least 3 years in patients with diabetic macular edema. Ophthalmology 2012, 119, 2125-2132. [CrossRef] [PubMed]

127. Schmidt-Erfurth, U.; Garcia-Arumi, J.; Bandello, F.; Berg, K.; Chakravarthy, U.; Gerendas, B.S.; Jonas, J.; Larsen, M.; Tadayoni, R.; Loewenstein, A. Guidelines for the Management of Diabetic Macular Edema by the European Society of Retina Specialists (EURETINA). Ophthalmologica 2017, 237, 185-222. [CrossRef]

128. Suganya, N.; Bhakkiyalakshmi, E.; Sarada, D.V.; Ramkumar, K.M. Reversibility of endothelial dysfunction in diabetes: Role of polyphenols. Br. J. Nutr. 2016, 116, 223-246. [CrossRef] 
129. Lafuente, M.; Ortin, L.; Argente, M.; Guindo, J.L.; Lopez-Bernal, M.D.; Lopez-Roman, F.J.; Domingo, J.C.; Lajara, J. ThreeYear Outcomes in a Randomized Single-Blind Controlled Trial of Intravitreal Ranibizumab and Oral Supplementation with Docosahexaenoic Acid and Antioxidants for Diabetic Macular Edema. Retina 2019, 39, 1083-1090. [CrossRef]

130. Rossino, M.G.; Casini, G. Nutraceuticals for the Treatment of Diabetic Retinopathy. Nutrients 2019, 11, 771. [CrossRef]

131. Safi, S.Z.; Qvist, R.; Kumar, S.; Batumalaie, K.; Ismail, I.S. Molecular mechanisms of diabetic retinopathy, general preventive strategies, and novel therapeutic targets. Biomed. Res. Int. 2014, 2014, 801269. [CrossRef]

132. Li, C.; Miao, X.; Li, F.; Wang, S.; Liu, Q.; Wang, Y.; Sun, J. Oxidative Stress-Related Mechanisms and Antioxidant Therapy in Diabetic Retinopathy. Oxid. Med. Cell Longev. 2017, 2017, 9702820. [CrossRef]

133. Robles-Rivera, R.R.; Castellanos-Gonzalez, J.A.; Olvera-Montano, C.; Flores-Martin, R.A.; Lopez-Contreras, A.K.; ArevaloSimental, D.E.; Cardona-Munoz, E.G.; Roman-Pintos, L.M.; Rodriguez-Carrizalez, A.D. Adjuvant Therapies in Diabetic Retinopathy as an Early Approach to Delay Its Progression: The Importance of Oxidative Stress and Inflammation. Oxid. Med. Cell Longev. 2020, 2020, 3096470. [CrossRef] [PubMed]

134. Age-Related Eye Disease Study Research Group. A randomized, placebo-controlled, clinical trial of high-dose supplementation with vitamins $C$ and $E$ and beta carotene for age-related cataract and vision loss: AREDS report no. 9. Arch. Ophthalmol 2001, 119, 1439-1452. [CrossRef] [PubMed]

135. Pinazo-Duran, M.D.; Gallego-Pinazo, R.; Garcia-Medina, J.J.; Zanon-Moreno, V.; Nucci, C.; Dolz-Marco, R.; Martinez-Castillo, S.; Galbis-Estrada, C.; Marco-Ramirez, C.; Lopez-Galvez, M.I.; et al. Oxidative stress and its downstream signaling in aging eyes. Clin. Interv. Aging 2014, 9, 637-652. [CrossRef] [PubMed]

136. Balasaheb, S.; Pal, D. Free radicals, natural antioxidants, and their reaction mechanisms. RSC Adv. 2015, 5, 27986. [CrossRef]

137. Suksomboon, N.; Poolsup, N.; Juanak, N. Effects of coenzyme Q10 supplementation on metabolic profile in diabetes: A systematic review and meta-analysis. J. Clin. Pharm. Ther. 2015, 40, 413-418. [CrossRef] [PubMed]

138. Agbor, G.A.; Vinson, J.A.; Patel, S.; Patel, K.; Scarpati, J.; Shiner, D.; Wardrop, F.; Tompkins, T.A. Effect of selenium- and glutathione-enriched yeast supplementation on a combined atherosclerosis and diabetes hamster model. J. Agric. Food Chem. 2007, 55, 8731-8736. [CrossRef]

139. Ajith, T.A. Alpha-lipoic acid: A possible pharmacological agent for treating dry eye disease and retinopathy in diabetes. Clin. Exp. Pharmacol. Physiol. 2020, 47, 1883-1890. [CrossRef]

140. Eynard, A.R.; Repossi, G. Role of omega3 polyunsaturated fatty acids in diabetic retinopathy: A morphological and metabolically cross talk among blood retina barriers damage, autoimmunity and chronic inflammation. Lipids Health Dis. $2019,18,114$. [CrossRef]

141. Zhang, X.; Liu, W.; Wu, S.; Jin, J.; Li, W.; Wang, N. Calcium dobesilate for diabetic retinopathy: A systematic review and meta-analysis. Sci. China Life Sci. 2015, 58, 101-107. [CrossRef]

142. Garcia-Medina, J.J.; Rubio-Velazquez, E.; Lopez-Bernal, M.D.; Cobo-Martinez, A.; Zanon-Moreno, V.; Pinazo-Duran, M.D.; Del-Rio-Vellosillo, M. Glaucoma and Antioxidants: Review and Update. Antioxidants 2020, 9, 1031. [CrossRef]

143. Pellegrini, M.; Senni, C.; Bernabei, F.; Cicero, A.F.G.; Vagge, A.; Maestri, A.; Scorcia, V.; Giannaccare, G. The Role of Nutrition and Nutritional Supplements in Ocular Surface Diseases. Nutrients 2020, 12, 952. [CrossRef] [PubMed]

144. Chous, A.P.; Richer, S.P.; Gerson, J.D.; Kowluru, R.A. The Diabetes Visual Function Supplement Study (DiVFuSS). Br. J. Ophthalmol. 2016, 100, 227-234. [CrossRef] [PubMed]

145. Sanz-Gonzalez, S.M.; Garcia-Medina, J.J.; Zanon-Moreno, V.; Lopez-Galvez, M.I.; Galarreta-Mira, D.; Duarte, L.; Valero-Vello, M.; Ramirez, A.I.; Arevalo, J.F.; Pinazo-Duran, M.D.; et al. Clinical and Molecular-Genetic Insights into the Role of Oxidative Stress in Diabetic Retinopathy: Antioxidant Strategies and Future Avenues. Antioxidants 2020, 9, 1101. [CrossRef] [PubMed]

146. Moon, S.W.; Shin, Y.U.; Cho, H.; Bae, S.H.; Kim, H.K.; for the Mogen Study Group. Effect of grape seed proanthocyanidin extract on hard exudates in patients with non-proliferative diabetic retinopathy. Medicine 2019, 98, e15515. [CrossRef] [PubMed]

147. Sepahi, S.; Mohajeri, S.A.; Hosseini, S.M.; Khodaverdi, E.; Shoeibi, N.; Namdari, M.; Tabassi, S.A.S. Effects of Crocin on Diabetic Maculopathy: A Placebo-Controlled Randomized Clinical Trial. Am. J. Ophthalmol. 2018, 190, 89-98. [CrossRef]

148. Zhang, P.C.; Wu, C.R.; Wang, Z.L.; Wang, L.Y.; Han, Y.; Sun, S.L.; Li, Q.S.; Ma, L. Effect of lutein supplementation on visual function in nonproliferative diabetic retinopathy. Asia Pac. J. Clin. Nutr. 2017, 26, 406-411. [CrossRef]

149. Lafuente, M.; Ortin, L.; Argente, M.; Guindo, J.L.; Lopez-Bernal, M.D.; Lopez-Roman, F.J.; Garcia, M.J.; Domingo, J.C.; Lajara, J. Combined intravitreal ranibizumab and oral supplementation with docosahexaenoic acid and antioxidants for diabetic macular edema: Two-Year Randomized Single-Blind Controlled Trial Results. Retina 2017, 37, 1277-1286. [CrossRef] [PubMed]

150. Rodriguez-Carrizalez, A.D.; Castellanos-Gonzalez, J.A.; Martinez-Romero, E.C.; Miller-Arrevillaga, G.; Pacheco-Moises, F.P.; Roman-Pintos, L.M.; Miranda-Diaz, A.G. The effect of ubiquinone and combined antioxidant therapy on oxidative stress markers in non-proliferative diabetic retinopathy: A phase IIa, randomized, double-blind, and placebo-controlled study. Redox Rep. 2016, 21, 155-163. [CrossRef] [PubMed]

151. Roig-Revert, M.J.; Lleo-Perez, A.; Zanon-Moreno, V.; Vivar-Llopis, B.; Marin-Montiel, J.; Dolz-Marco, R.; Alonso-Munoz, L.; Albert-Fort, M.; Lopez-Galvez, M.I.; Galarreta-Mira, D.; et al. Enhanced Oxidative Stress and Other Potential Biomarkers for Retinopathy in Type 2 Diabetics: Beneficial Effects of the Nutraceutic Supplements. Biomed. Res. Int. 2015, 2015, 408180. [CrossRef] 
152. Domanico, D.; Fragiotta, S.; Cutini, A.; Carnevale, C.; Zompatori, L.; Vingolo, E.M. Circulating levels of reactive oxygen species in patients with nonproliferative diabetic retinopathy and the influence of antioxidant supplementation: 6-month follow-up. Indian J. Ophthalmol. 2015, 63, 9-14. [CrossRef] [PubMed]

153. Watanabe, K.; Shimada, A.; Miyaki, K.; Hirakata, A.; Matsuoka, K.; Omae, K.; Takei, I. Long-term effects of goshajinkigan in prevention of diabetic complications: A randomized open-labeled clinical trial. Evid. Based Complement. Alternat. Med. 2014, 2014, 128726. [CrossRef] [PubMed]

154. Haritoglou, C.; Gerss, J.; Hammes, H.P.; Kampik, A.; Ulbig, M.W.; RETIPON Study Group. Alpha-lipoic acid for the prevention of diabetic macular edema. Ophthalmologica 2011, 226, 127-137. [CrossRef] [PubMed]

155. Garcia-Medina, J.J.; Pinazo-Duran, M.D.; Garcia-Medina, M.; Zanon-Moreno, V.; Pons-Vazquez, S. A 5-year follow-up of antioxidant supplementation in type 2 diabetic retinopathy. Eur. J. Ophthalmol. 2011, 21, 637-643. [CrossRef] [PubMed]

156. Forte, R.; Cennamo, G.; Finelli, M.L.; Bonavolonta, P.; de Crecchio, G.; Greco, G.M. Combination of flavonoids with Centella asiatica and Melilotus for diabetic cystoid macular edema without macular thickening. J. Ocul Pharmacol. Ther. 2011, 27, 109-113. [CrossRef] [PubMed]

157. Bursell, S.E.; Clermont, A.C.; Aiello, L.P.; Aiello, L.M.; Schlossman, D.K.; Feener, E.P.; Laffel, L.; King, G.L. High-dose vitamin E supplementation normalizes retinal blood flow and creatinine clearance in patients with type 1 diabetes. Diabetes Care 1999, 22, 1245-1251. [CrossRef]

158. Elliott, C. Assessing Vitamins, Minerals and Supplements Marketed to Children in Canada. Int. J. Environ. Res. Public Health 2019, 16, 4326. [CrossRef]

159. Jafari, S.M.; McClements, D.J. Nanotechnology Approaches for Increasing Nutrient Bioavailability. Adv. Food Nutr. Res. 2017, 81, 1-30. [CrossRef]

160. Kapetanovic, I.M.; Muzzio, M.; Huang, Z.; Thompson, T.N.; McCormick, D.L. Pharmacokinetics, oral bioavailability, and metabolic profile of resveratrol and its dimethylether analog, pterostilbene, in rats. Cancer Chemother. Pharmacol. 2011, 68, 593-601. [CrossRef]

161. Aiello, L.P.; Odia, I.; Glassman, A.R.; Melia, M.; Jampol, L.M.; Bressler, N.M.; Kiss, S.; Silva, P.S.; Wykoff, C.C.; Sun, J.K.; et al. Comparison of Early Treatment Diabetic Retinopathy Study Standard 7-Field Imaging With Ultrawide-Field Imaging for Determining Severity of Diabetic Retinopathy. JAMA Ophthalmol. 2019, 137, 65-73. [CrossRef]

162. Spaide, R.F.; Klancnik, J.M., Jr.; Cooney, M.J. Retinal vascular layers in macular telangiectasia type 2 imaged by optical coherence tomographic angiography. JAMA Ophthalmol. 2015, 133, 66-73. [CrossRef]

163. Spaide, R.F.; Klancnik, J.M., Jr.; Cooney, M.J. Retinal vascular layers imaged by fluorescein angiography and optical coherence tomography angiography. JAMA Ophthalmol. 2015, 133, 45-50. [CrossRef]

164. Bradley, P.D.; Sim, D.A.; Keane, P.A.; Cardoso, J.; Agrawal, R.; Tufail, A.; Egan, C.A. The Evaluation of Diabetic Macular Ischemia Using Optical Coherence Tomography Angiography. Investig. Ophthalmol. Vis. Sci. 2016, 57, 626-631. [CrossRef] [PubMed]

165. Schmidt-Erfurth, U.; Sadeghipour, A.; Gerendas, B.S.; Waldstein, S.M.; Bogunovic, H. Artificial intelligence in retina. Prog. Retin Eye Res. 2018, 67, 1-29. [CrossRef]

166. Ting, D.S.W.; Pasquale, L.R.; Peng, L.; Campbell, J.P.; Lee, A.Y.; Raman, R.; Tan, G.S.W.; Schmetterer, L.; Keane, P.A.; Wong, T.Y. Artificial intelligence and deep learning in ophthalmology. Br. J. Ophthalmol. 2019, 103, 167-175. [CrossRef] [PubMed]

167. Whitehead, M.; Wickremasinghe, S.; Osborne, A.; Van Wijngaarden, P.; Martin, K.R. Diabetic retinopathy: A complex pathophysiology requiring novel therapeutic strategies. Expert Opin. Biol. Ther. 2018, 18, 1257-1270. [CrossRef] [PubMed] 